\title{
Assessment of Aquatic Macroinvertebrates on USFS / BLM Lands of the Crooked and Sage Creek Watersheds
}

Prepared for Darin Watschke, USFS Custer National Forest, Billings, Agreement 05-CS-11015600-036

by

David M. Stagliano

Aquatic Ecologist

August 2009

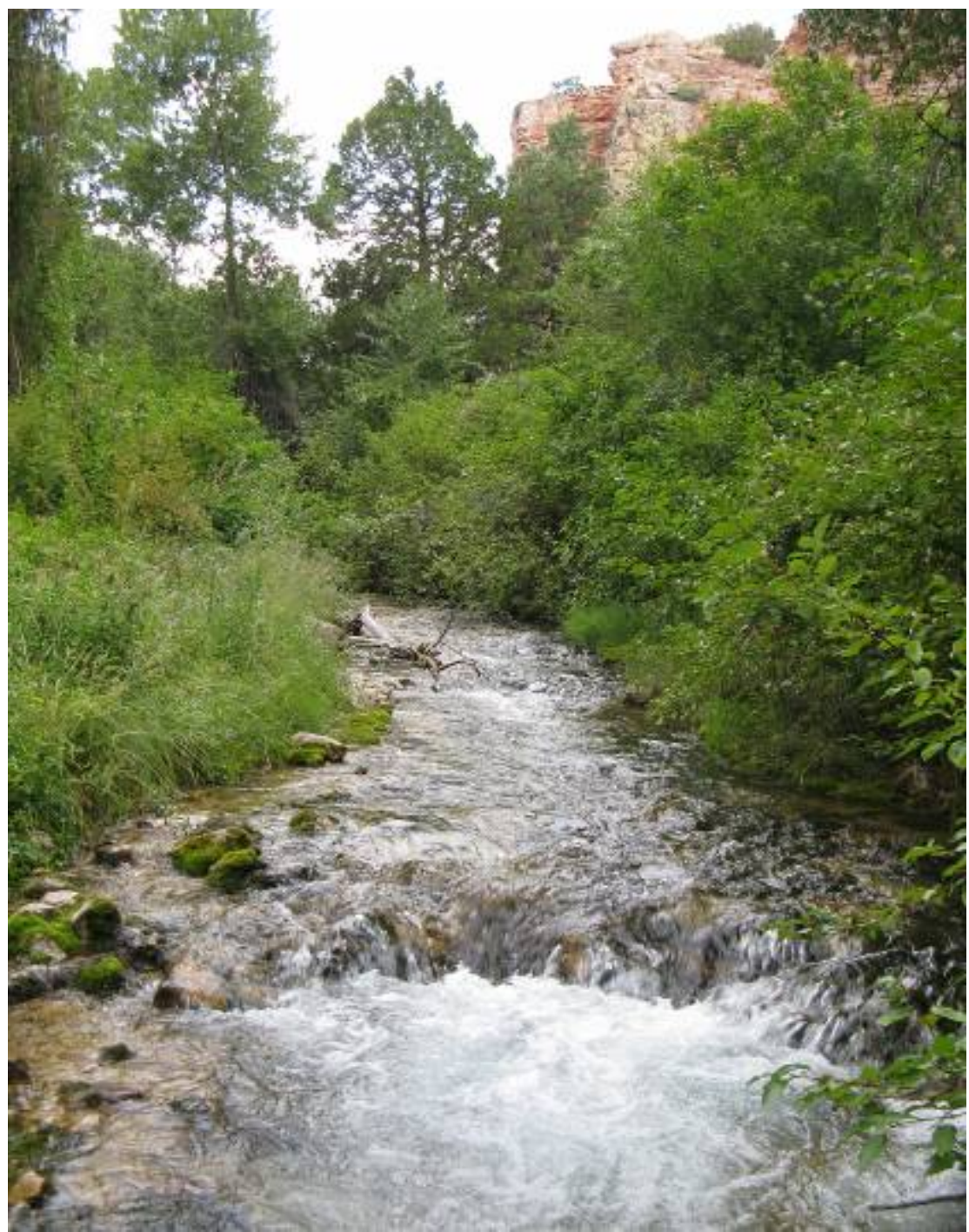

Crooked Creek upstream of Fish Exclusion Barrier

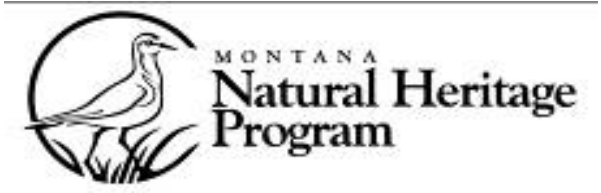




\section{Acknowledgements}

We would like to thank Darrin Watschke, USFS Custer Forest in the Billings Office, and Ann Carlson of the USFS Region 1 office in Missoula for implementing the agreement 05-CS11015600-036 from which most of the macroinvertebrate work is taking place. Meghan Burns expertly provided the GIS map and Amandi Standley helped process the macroinvertebrate samples. Paul Hendricks, MTNHP identified the terrestrial snails collected during this site visits.

All photos in the report were taken by MTNHP personnel, unless otherwise noted 


\section{Crooked and Sage Creek Watershed Aquatic Assessment}

\section{Objectives.}

Project goals of the 2008 MTNHP Aquatic Surveys of the Crooked and Sage Creek Watersheds were: 1) to sample and assess aquatic macroinvertebrate community integrity and diversity in relation to the Crooked Creek fish exclusion barrier completed in 2007; compare upstream and downstream macroinvertebrate communities.

2) to evaluate additional aquatic sites in the area of interest potentially containing unique, species of concern (SOC) or important indicator macroinvertebrate taxa in relation to future restoration projects (i.e., Sage Creek).

\section{Habitat Evaluations.}

On-site habitat assessments were conducted using the rapid assessment protocol (RBP Level 1, scores 0-200) developed for the EPA by Barbour et al. (1999) with modifications and additions by the National Aquatic Assessment of the Bureau of Land Management (BLM)(scores 0-24) (http://www1.usu.edu/buglab/forms/Bug\%20Protocol\%20form.pdf). Using the BLM assessment protocols, the reach was divided into 10 equally spaced transects. Parameters recorded at each were: wetted width, bankfull width, 3 channel depth measurements, large woody debris, riparian shading and benthic substrate (in \% composition per transect) based on Wollman size-classes were measured at each transect perpendicular to the stream channel. Basic water chemistry parameters (temperature, $\mathrm{pH}$, conductivity) were recorded prior to sampling using a Horiba $\mathrm{H}-10$ water monitor. The goal of these evaluations is to characterize local reach geomorphology, riparian and in-stream habitat, and other characteristics that influence aquatic community integrity. The LUI (Livestock Use Index) was also incorporated into the riparian habitat assessment, this involved a $75 \mathrm{~m}$ zig-zag walk from the bottom of the reach on the left and right banks of the stream channel visually counting the number of cow pies, and noting if these are new or old (see BLM Assessment Sheet:

http://www1.usu.edu/buglab/forms/Bug\%20Protocol.pdf). Sites ranking higher using these protocols are determined to have higher quality local-scale habitat. Habitat assessments were performed during the same visit as the biological sampling.

\section{Macroinvertebrate Communities:}

Macroinvertebrates were collected from riffle geomorphic habitat units from evenly spaced transects along and across the reach with a 500-micron D-frame net (8 discrete samples). This method follows the EMAP Targeted Riffle protocol outlined in Lazorchak (1998) and modified for the BLM National Monitoring Lab (http://www1.usu.edu/buglab/forms/Bug\%20Protocol.pdf)

All 8 samples $\left(8 \times 0.075 \mathrm{~m}^{2}\right)$ taken within the transects were composited into a 5 gallon bucket, and the organisms were washed onto a 500-micron sieve, transferred to a 1 liter Nalgene bottle, labeled and preserved in 95\% ethanol and brought to the MTNHP lab in Helena for processing. Small, low volume (trickle) spring macroinvertebrate samples (Sage Creek Campground Spring, Commissary Creek Spring) were collected opportunistically with dipnets and aquarium nets 
covering all habitats within the reach. Moss samples $\left(1 \mathrm{ft}^{2}\right)$ taken above the fish barrier were measured with a ruler and scraped off the cobbles by hand so as not to disturb the underlying cobbles.

Figure 1. EMAP Targeted Riffle Composite protocol used in macroinvertebrate collection.

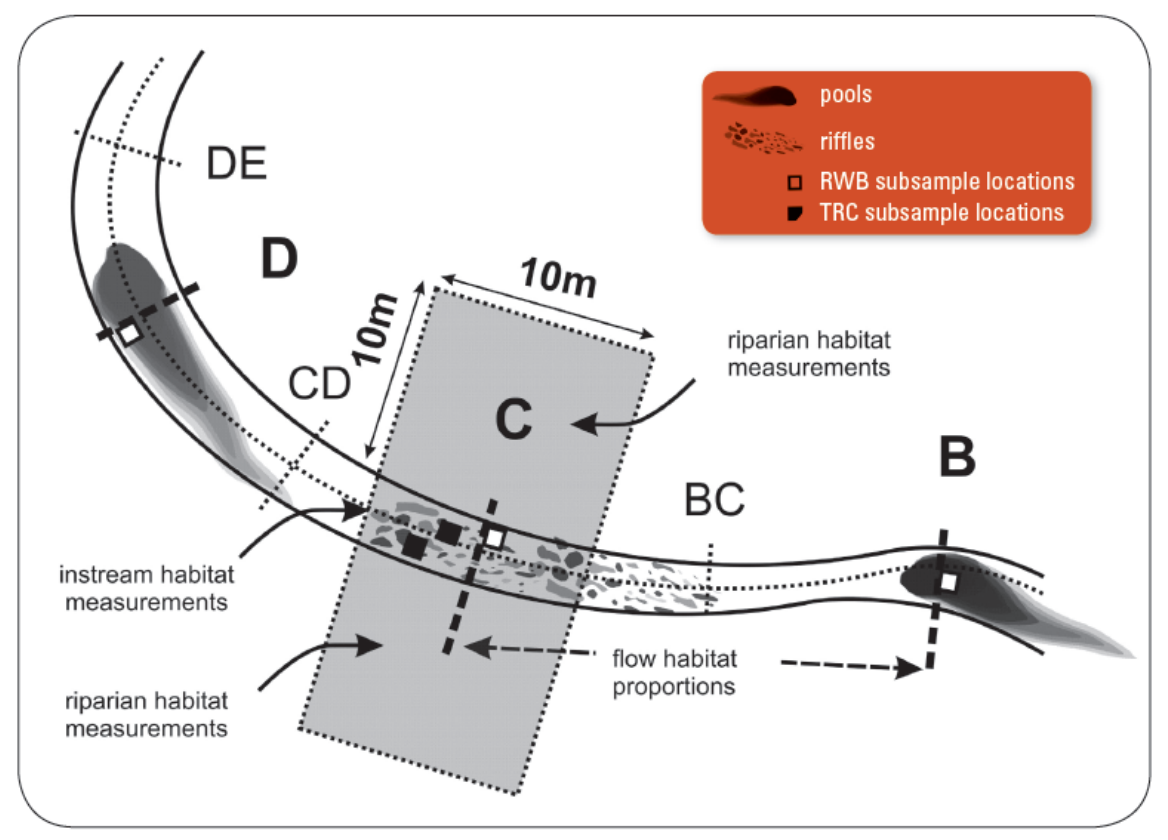

Samples were processed (sorting, identification, and data analysis) by the author (D. Stagliano) at the Helena NHP lab following BLM National Aquatic Monitoring Methods (sensu stricto EMAP protocols Lazorchak et. al.1998). Macroinvertebrates (500 individuals per sample when available) were identified to the lowest taxonomic level, imported into EDAS (Jessup 2006), and biological integrity metrics were calculated from the data using the newest multimetric macroinvertebrate (MMI) protocols (Jessup et al. 2005, Feldman 2006). Metric results were then scored using the Montana DEQ bioassessment criteria and each sample categorized as nonimpaired or impaired according to threshold values (Table 1). The impairment threshold set by MT DEQ is 48 for the Low Mountain/Valley Index and 63 for the Mountain Index thus any scores above this threshold are considered unimpaired.

Table 1. Impairment determinations from the MMI and O/E (RIVPACS) models (taken from Jessup 2005, Feldman 2006).

\begin{tabular}{|l|l|l|l|l|} 
Ecoregion & RIVACS & MMU & Impairment Determination \\
\hline Mountain & $\geq 0.8$ or $\leq 1.2$ & $\geq 63$ & Not impaired \\
& $<0.8$ or $>1.2$ & $<63$ & $\begin{array}{l}\text { Impaired } \\
\text { Low Valley }\end{array}$ \\
& $\geq 0.8$ or $\leq 1.2$ & $\geq 48$ & Not impaired \\
& $<0.8$ or $>1.2$ & $<48$ & Impaired \\
\hline \multirow{2}{*}{ Eastern Plains } & $\geq 0.8$ or $\leq 1.2$ & $\geq 37$ & Not impaired \\
& $<0.8$ or $>1.2$ & $<37$ & Impaired
\end{tabular}


The macroinvertebrate MMI score is based upon a series of metrics that measure attributes of benthic macroinvertebrate communities correlating with changes to a stream system (in the form of anthropogenic caused changes). There are no existing DEQ impairment criteria for Spring Macroinvertebrate Communities; therefore, we consider the comparison of observed taxa vs. expected "reference condition taxa" from similar springs in the ecoregion (see Stagliano 2008).

\section{Study Sites}

All sites chosen for this USFS Crooked/Sage Creek stream evaluation \& watershed assessment lie within the USFS Custer National Forest (Pryor Mountains) or the BLM Billings Field Office Management Area in Carbon Co., MT (Figure 2). Habitat assessments, water quality measurements and macroinvertebrate samples were performed in 2008 at 13 lotic sites, 7 of these were pre-determined (per conversation with D. Watschke), and an additional 6 spring-influenced sites within the USFS lands were discovered while accessing other areas of the assessment region (Table 2), 3 sites included in this assessment were sampled in 2007. Three of the apriori chosen stream sites (Cave, Lost Water, and lower Commissary Creek) as well as 9 other randomly visited sites were dry (Table 2). Biological community integrity was calculated at all sites using the macroinvertebrate multi-metrics (MT DEQ MMI’s). Site summary descriptions based on the overall community integrity and site observations are included.

Figure 2. Sites visited in the USFS Pryors and BLM lands of the Crooked \& Sage Creek Watersheds. Ecological Biointegrity Values are based on habitat evaluations \& macroinvertebrate communities (see Methods).

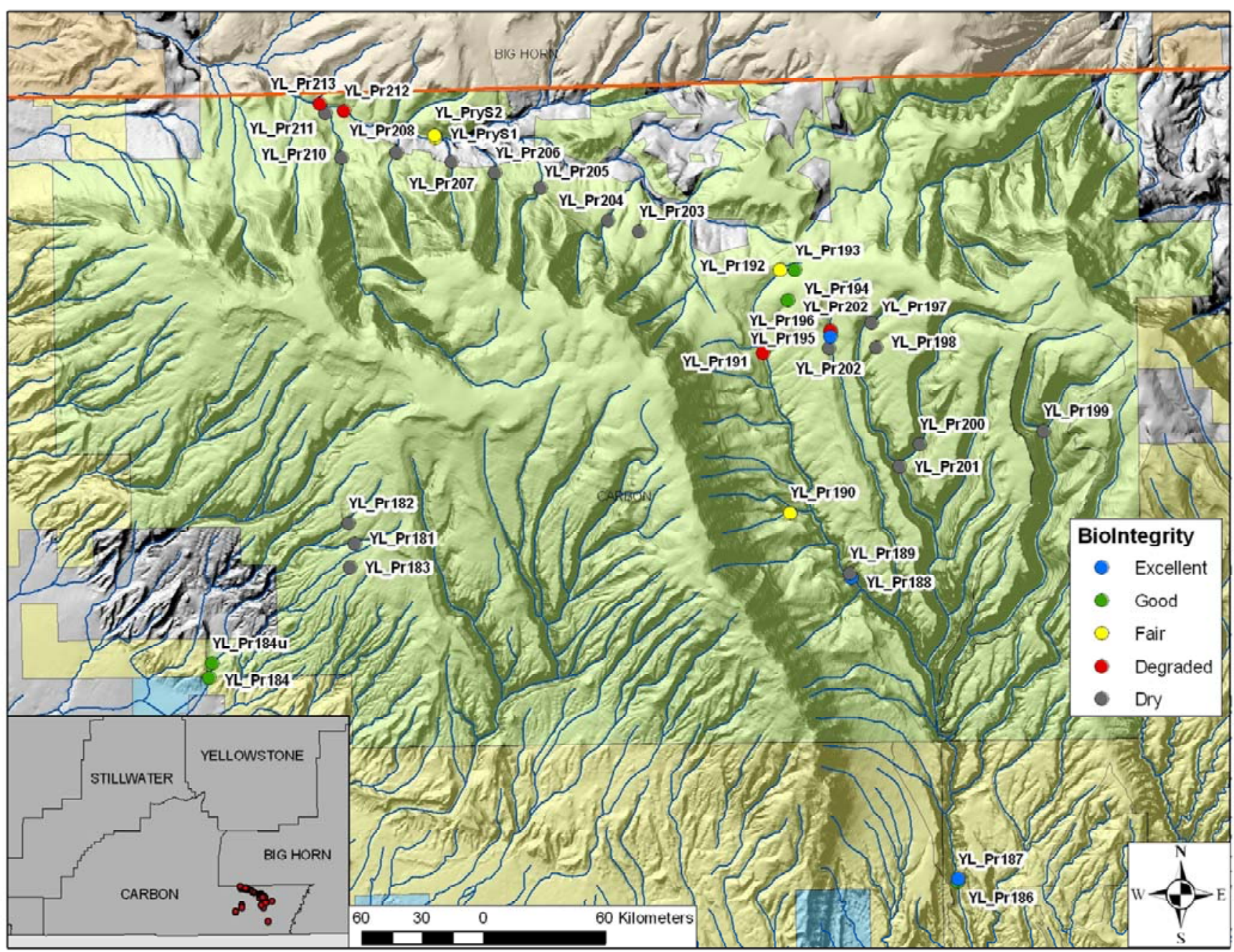


Table 2. USFS Custer Forest Pryor 2008 project sites visited Sept. $3^{\text {rd }}-5$ th. Sites with an asterisk $(*)$ were sampled by NHP in 2007 during another project visit.

\begin{tabular}{|c|c|c|c|c|c|c|c|}
\hline Site Code & Sites Visited & HUC & Latitude & Longitude & $\begin{array}{c}\text { Elev } \\
\text { (ft) }\end{array}$ & Water Flow & $\begin{array}{l}\text { Macro } \\
\text { Sample }\end{array}$ \\
\hline YL_Pr181 & Piney Creek trib & 10080014 & 45.1290 & -108.5551 & 6601 & dry & \multirow{6}{*}{$\begin{array}{l}\mathbf{X} \\
\mathbf{X}\end{array}$} \\
\hline YL_Pr182 & Piney Creek trib & 10080014 & 45.1332 & -108.5567 & 6743 & dry & \\
\hline YL_Pr183 & Piney Creek trib & 10080014 & 45.1245 & -108.5565 & 6506 & dry & \\
\hline YL_Pr184 & Piney Creek (BLM) & 10080014 & 45.1031 & -108.5958 & 5022 & flowing & \\
\hline YL_Pr184u & Piney Creek (USFS)* & 10080014 & 45.1060 & -108.5950 & 5031 & flowing & \\
\hline YL_Pr185 & $\begin{array}{l}\text { Rattlesnake (CRVI) } \\
\text { Demijohn Flat }\end{array}$ & 10080010 & 45.0805 & -108.4002 & 5659 & upland & \\
\hline YL_Pr186 & Crooked Creek blwb & 10080010 & 45.0610 & -108.3893 & 5620 & flowing & $\mathbf{X}$ \\
\hline YL_Pr187 & Crooked Creek abvb & 10080010 & 45.0617 & -108.3890 & 5645 & flowing & $\mathbf{X}$ \\
\hline YL_Pr188 & Crooked Creek upper & 10080010 & 45.1213 & -108.4176 & 5726 & flowing & \multirow{2}{*}{$\begin{array}{l}\mathbf{X} \\
\mathbf{X}\end{array}$} \\
\hline YL_Pr189 & Crooked Creek trib & 10080010 & 45.1220 & -108.4180 & 5792 & dry & \\
\hline YL_Pr190 & Wyoming Creek & 10080010 & 45.1341 & -108.4342 & 6177 & flowing & \multirow{6}{*}{$\begin{array}{l}\mathbf{X} \\
\mathbf{X} \\
\mathbf{X} \\
\mathbf{X} \\
\mathbf{X}\end{array}$} \\
\hline YL_Pr191 & Crooked Creek trib & 10080010 & 45.1655 & -108.4412 & 6631 & flowing & \\
\hline YL_Pr192 & Crooked Creek source & 10080010 & 45.1818 & -108.4361 & 7101 & flowing & \\
\hline YL_Pr193 & Crooked Creek Spring & 10080010 & 45.1818 & -108.4320 & 7240 & flowing & \\
\hline YL_Pr194 & Crooked Creek trib & 10080010 & 45.1758 & -108.4341 & 7172 & flowing & \\
\hline YL_Pr195 & Commissary Creek trib & 10080010 & 45.1695 & -108.4234 & 7329 & dry & \\
\hline YL_Pr196 & Commissary Creek & 10080010 & 45.1698 & -108.4225 & 7279 & trickle flow & \multirow[t]{6}{*}{$\mathbf{X}$} \\
\hline YL_Pr197 & Cave Creek trib & 10080010 & 45.1712 & -108.4111 & 7332 & dry & \\
\hline YL_Pr198 & Cave Creek trib & 10080010 & 45.1664 & -108.4098 & 7403 & dry & \\
\hline YL_Pr199 & Lost Water Creek & 10080010 & 45.1494 & -108.3637 & 7196 & dry & \\
\hline YL_Pr200 & Cave Creek & 10080010 & 45.1472 & -108.3980 & 6700 & dry & \\
\hline YL_Pr201 & Cave Creek trib & 10080010 & 45.1663 & -108.4228 & 7194 & dry & \\
\hline YL_Pr202 & Rock Spring trib & 10080010 & 45.1686 & -108.4225 & 7316 & trickle flow & \multirow[t]{9}{*}{$\mathbf{X}$} \\
\hline YL_Pr203 & Sage Creek trib & 10080014 & 45.1897 & -108.4752 & 6702 & dry & \\
\hline YL_Pr204 & Sage Creek trib & 10080014 & 45.1920 & -108.4836 & 6677 & dry & \\
\hline YL_Pr205 & Sage Creek trib & 10080014 & 45.1985 & -108.5023 & 6602 & dry & \\
\hline YL_Pr206 & Sage Creek trib & 10080014 & 45.2017 & -108.5150 & 6654 & dry & \\
\hline YL_Pr207 & Sage Creek trib & 10080014 & 45.2039 & -108.5269 & 6624 & dry & \\
\hline YL_Pr208 & Sage Creek trib & 10080014 & 45.2058 & -108.5422 & 6612 & dry & \\
\hline YL_Pr210 & Sage Creek trib & 10080014 & 45.2049 & -108.5574 & 6588 & dry & \\
\hline YL_Pr211 & Sage Creek trib & 10080014 & 45.2137 & -108.5619 & 6576 & dry & \\
\hline YL_Pr212 & Sage Creek & 10080014 & 45.2141 & -108.5565 & 5524 & flowing & $\mathbf{X}$ \\
\hline YL_Pr213 & Sage Creek & 10080014 & 45.2156 & -108.5632 & 5520 & flowing & $\mathbf{X}$ \\
\hline YL_PryS1 & Sage Creek Spring * & 10080014 & 45.2087 & -108.5314 & 5724 & trickle flow & $\mathbf{X}$ \\
\hline YL_PryS2 & $\begin{array}{l}\text { Sage Creek Spring * } \\
\text { Sagebrush Lizard }\end{array}$ & 10080014 & 45.2091 & -108.5316 & 5753 & trickle flow & $\mathbf{X}$ \\
\hline YL_Pr214 & (SCGR) incidental & 10080014 & 45.2159 & -108.5618 & 5571 & upland & \\
\hline
\end{tabular}




\section{$\underline{\text { Results Summary }}$}

The Crooked \& Sage Creek watersheds of the Bighorn River and Shoshone Basins are typical of Bighorn/Pryor Mountain Upland Douglas Fir/ Ponderosa Pine forest transitioning to a sagedominated Wyoming Basin landscape. We identified macroinvertebrate communities with moderate-excellent ecological integrity within 3 Aquatic Ecological System Types (AES) during this study: Small Transitional Foothills Streams (C001y), Small Headwater Forested Streams (D001y), and Northwestern Great Plains/Wyoming Basin Perennial Springs (S005). But significant anthropogenic factors exist in this region (ex. Non-native fish introductions, water diversions, improper grazing practices) to render some streams of these aquatic ecological system types in an impaired biological health condition (Sage, Crooked Creek headwaters and Commissary Creek).

Habitat Evaluations. Overall, 6 of the 16 flowing lotic sites had good habitat quality ranked by at least one of the habitat assessment methods (Table 3). Five of the 16 sites were ranked slightly impaired and five moderately to severely impaired. Dry sites visited (19) were not assessed, but generally had fewer riparian and in-stream channel problems because of minimal cattle use. Highest site habitat scores using BLM habitat assessment methods were measured at the 3 canyon Crooked Creek (CC) sites (inaccessible to cattle), Piney Creek, and a tributary to Crooked Creek. Highest deductions to the riparian assessment scores were in stream sediments, $\%$ bare ground and bank trampling by cattle intrusions into the riparian zone. These intrusions were specifically measured using the Livestock Use Index (LUI), which was very high for multiple streams including Commissary Creek, headwaters of Crooked Creek, and Wyoming Creek. High sediment loading was documented at Wyoming Creek and both Sage Creek sites despite no overly obvious riparian disruptions in the immediate riparian area of the latter sites.

Macroinvertebrate Communities: Overall, 112 macroinvertebrate taxa were reported from the USFS Custer 2008 assessment sites (Appendix A). Average macroinvertebrate taxa richness per site was 24.67, and the highest taxa richness reported was 48 taxa at the CC site above barrier. Unique or infrequently collected taxa include Helichus striatus, a Dryopid riffle beetle collected only below the fish barrier and Meringodixa chalonensis, a cold-water obligate dipteran taxa found only in the CC tributary sample. The upper canyon Crooked Creek site (YL_Pr188) had the only reported collection of the cold-water caddisfly, Rhyacophila hyalinata gr. in good numbers; while Wyoming Creek reported the only occurrence of Rhyacophila oreta, a spring influenced associate caddisfly. Two unique riffle beetles, Lara avara and Narpus concolor were only reported from the Sage Creek sites; these are typically associated with large woody debris (LWD). Using the Montana DEQ multimetric index (MMI), 8 (10 samples) of the 16 sites were ranked non-impaired (good to excellent biological integrity), 4 were slightly impaired and 4 were moderately-severely impaired (Figure 2, Table 3).

All sample sites within the Crooked Creek canyon showed good to excellent benthic integrity. The progression of decreasing biointegrity (as measured by the DEQ MMI) as one proceeds up and out of the Crooked Creek Canyon is significant, and seems causally linked to increasing riparian degradation as cattle have access to the tributaries and mainstem of Crooked Creek (Figure 3).

Within Crooked Creek sample comparisons: there was no significant difference in macroinvertebrate community quality ranked by MT DEQ MMI above and below the barrier 
(Figure 2), but there was a slight difference in the furthest upstream Crooked Creek canyon site (MMI=85), which had more coldwater community taxa (Table 3).

Figure 3. Macroinvertebrate MMI scores from Crooked Creek (CC) below the fish barrier (FB) to the Source Spring. Dotted line is the impairment threshold score(63).

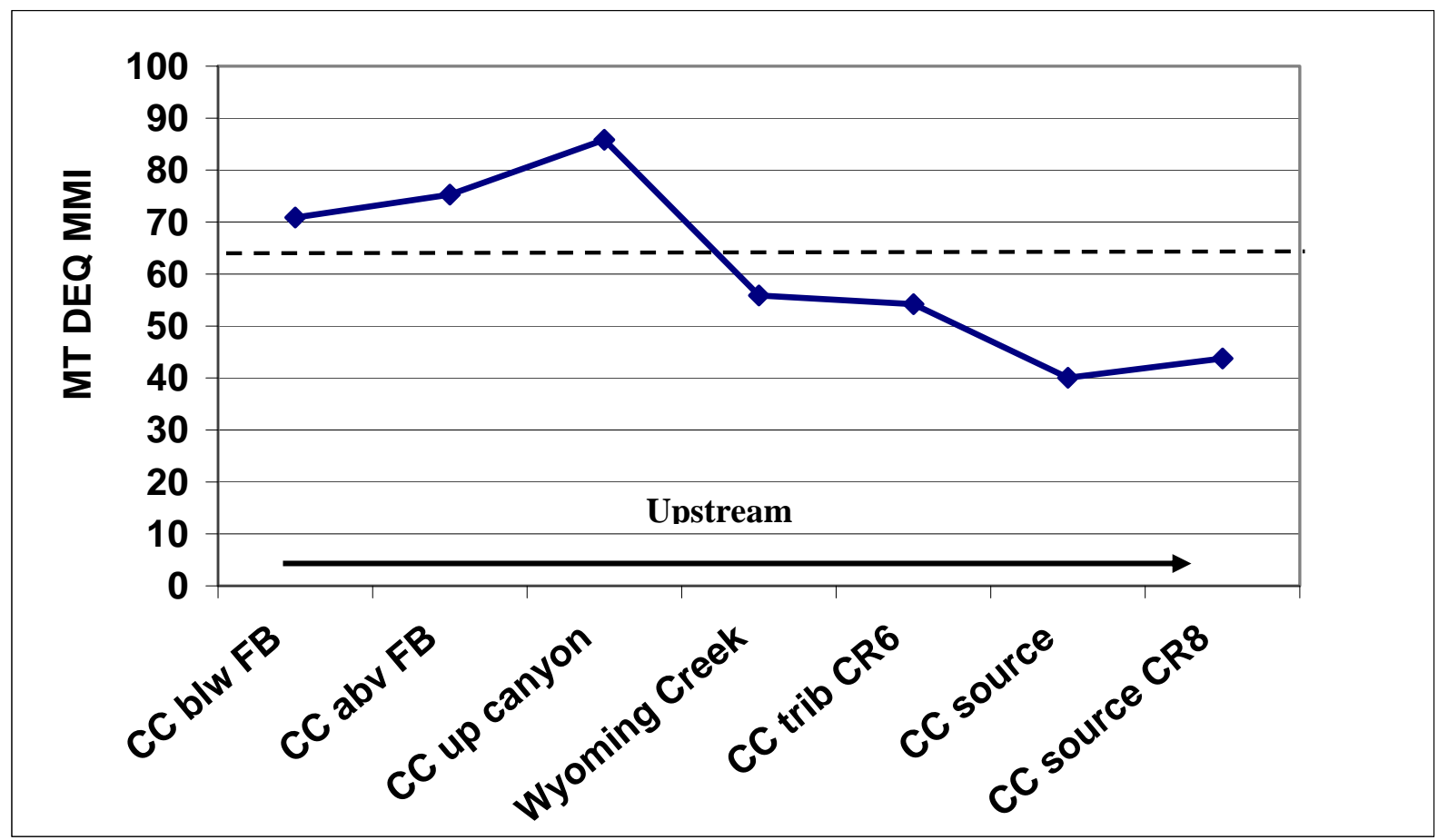

Figure 4. MMI scores from Crooked Creek (CC) above and below the fish barrier (FB). Error bars $=\mathrm{SE}(\mathrm{n}=2)$. Dotted line is the impairment threshold score (63).

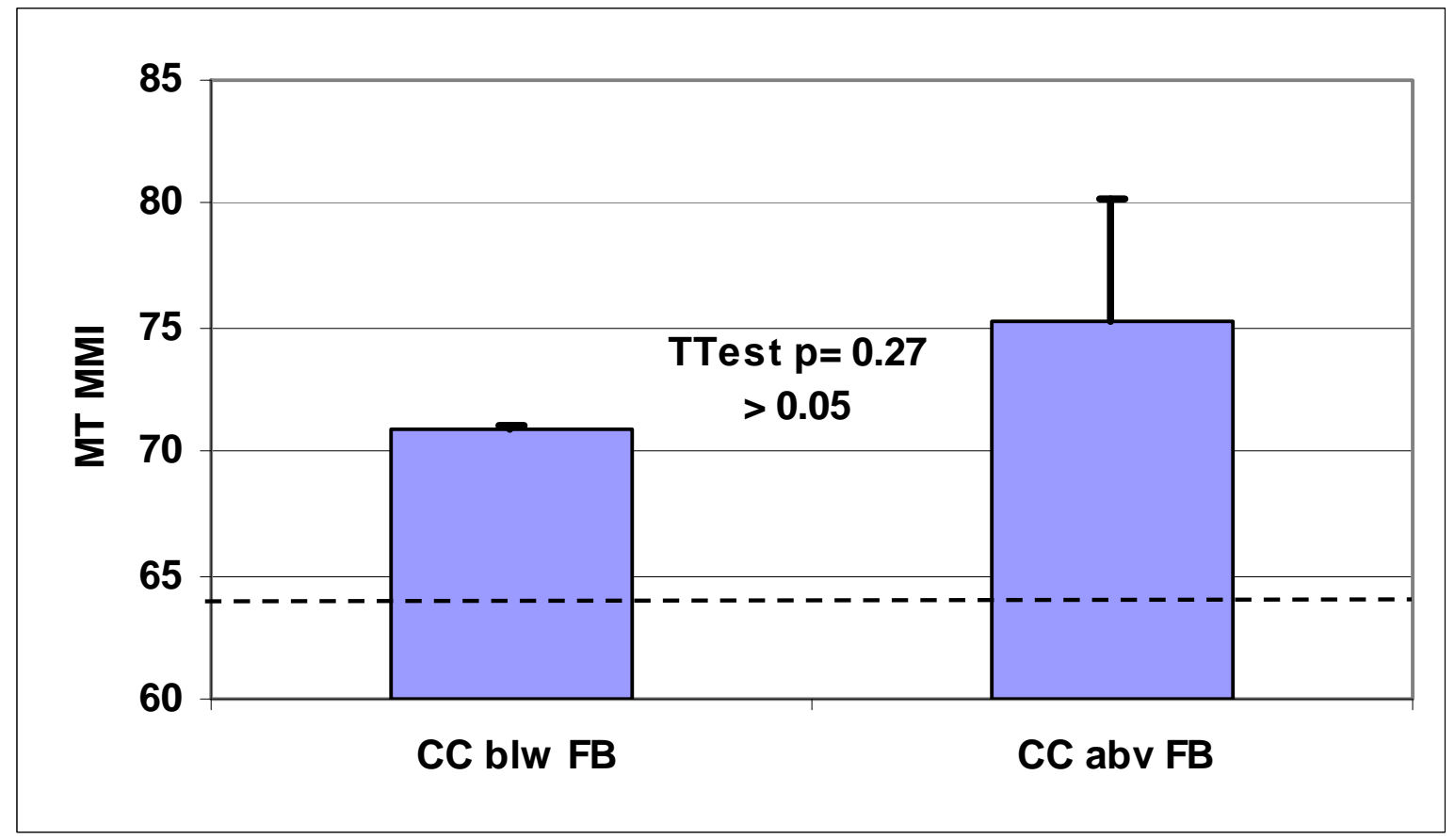


Despite no difference in the MMI scores above and below barrier, the species richness above the barrier is noticeably higher (42.5 vs. 29.5), but not significant (TTEST $=0.12$, unequal variances) (Table 3) and the coldwater taxa above far outnumber those below the barrier (15 vs. 8 spp.) The Hilsenhoff Biotic Index Scores (HBI: lower scores are better) indicate that the macroinvertebrate community downstream of the barrier is significantly more tolerant to organic enrichments (Figure 5).

Figure 5. HBI scores for Crooked Creek above and below the fish barrier (FB). Error bars=SE $(n=2)$.

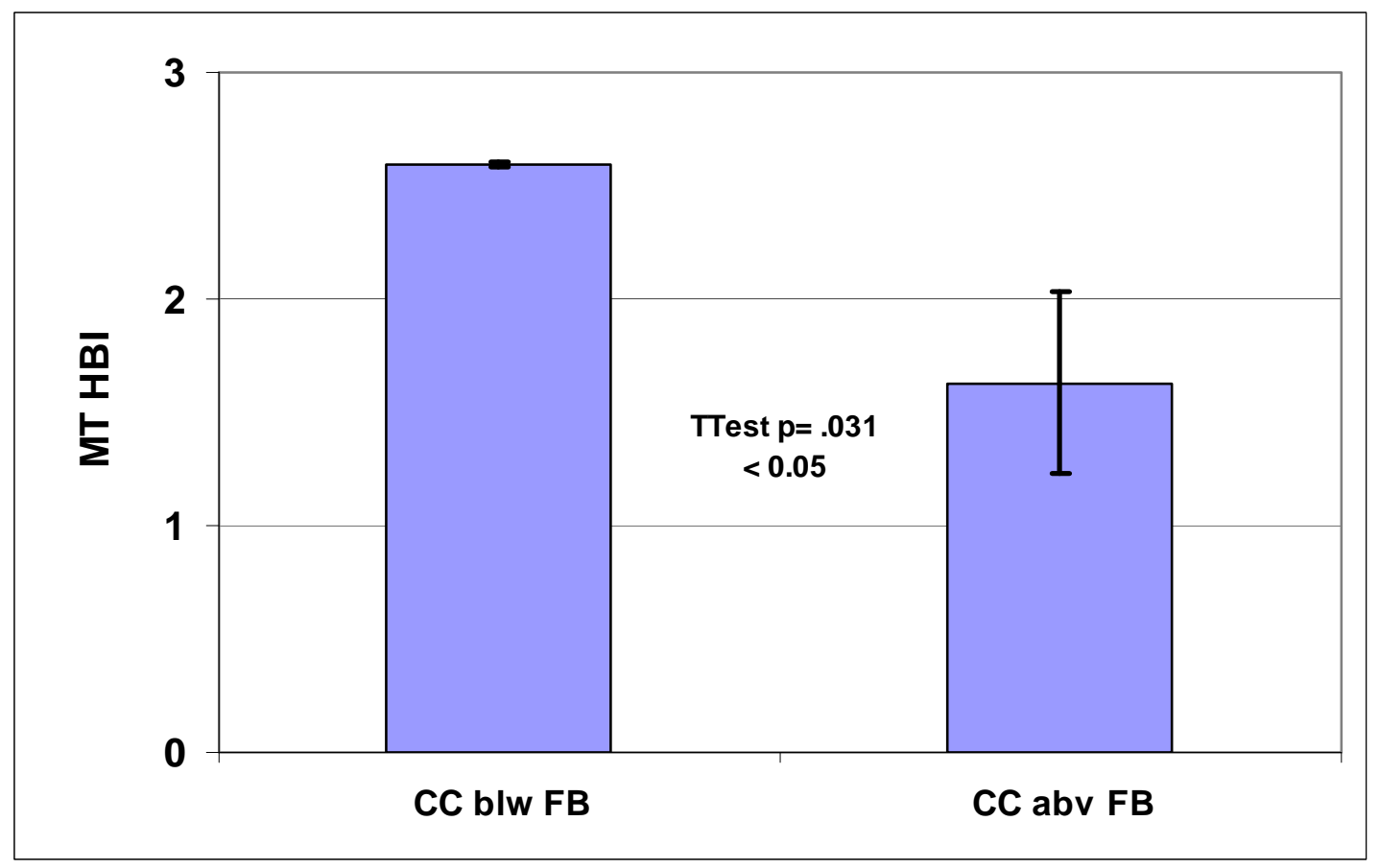

The moss grab samples resulted in a slightly different macroinvertebrate community than the whole composite. Moss grabs $\left(1 \mathrm{ft}^{2}\right)$ did not contain large stoneflies which prefer large cobble substrate, but had abundant mayfly, chironomid and caddisfly taxa with total numbers averaging 250 individuals per $\mathrm{ft}^{2}$ of moss or about 2,675 individuals per $\mathrm{m}^{2}$. Submerged moss growing on cobbles represented a significant portion of the benthic channel in the reaches above and below the barrier, averaging $2.0 \mathrm{~m}$ per $4.8 \mathrm{~m}$ wetted width or about $42 \%$ of benthic coverage (see red box in site photos). 
Table 3. Macroinvertebrate taxa richness, DEQ MMI= Multimetric Macroinvertebrate Index and Observed/Expected (O/E) scores for the spring sites. BLM Site Habitat Evaluation ( $>20=\mathrm{PFC}$ ), and WQ parameters LUI=Livestock Use Index, Cond =Conductivity. Bold-underlined scores are good-excellent index scores, shaded grey represent fair-good integrity conditions.

\begin{tabular}{|c|c|c|c|c|c|c|c|c|c|}
\hline Site Code & Sites Sampled & $\begin{array}{c}\text { BLM Site } \\
\text { Eval }\end{array}$ & $\begin{array}{c}\text { Taxa } \\
\text { Richness }\end{array}$ & MMI & $\mathbf{O} / \mathbf{E}$ & LUI & pH & Cond. & Temp. \\
\hline YL_Pr184 & Piney Creek (BLM land) & $19(79 \%)$ & 29 & 62.97 & na & 12 & 7.4 & 291 & 7.9 \\
\hline YL_Pr184u & Piney Creek Spring (USFS) & $\underline{21(88 \%)}$ & 9 & na & 0.55 & $\mathbf{0}$ & 7.3 & 277 & 7.2 \\
\hline YL_Pr186 & Crooked Creek blw barrier & $\underline{22}(92 \%)$ & $\underline{29}$ & $\underline{71.00}$ & na & $\mathbf{0}$ & 7.3 & 326 & 10.1 \\
\hline YL_Pr186_\#2 & Crooked Creek blw barrier & $22(92 \%)$ & 30 & 70.79 & na & $\mathbf{0}$ & 7.3 & 326 & 10.1 \\
\hline YL_Pr187 & Crooked Creek abv barrier & $24(100 \%)$ & $\underline{37}$ & $\underline{70.44}$ & na & $\mathbf{0}$ & 7.3 & 351 & 9.0 \\
\hline YL_Pr187_\#2 & Crooked Creek abv barrier & $24(100 \%)$ & $\underline{48}$ & $\overline{80.15}$ & na & $\mathbf{0}$ & 7.3 & 351 & 9.0 \\
\hline YL_Pr188 & Crooked Creek upper & $\underline{22(92 \%)}$ & 30 & 85.82 & na & $\mathbf{0}$ & 7.6 & 365 & 5.8 \\
\hline YL_Pr190 & Wyoming Creek & $18(75 \%)$ & $\overline{37}$ & $\overline{55.87}$ & na & 15 & 7.6 & 499 & 5.2 \\
\hline YL_Pr191 & Crooked Creek trib & $17(70 \%)$ & $\overline{30}$ & 54.20 & na & 28 & 7.6 & 403 & 5.4 \\
\hline YL_Pr192 & Crooked Creek source & $15(62 \%)$ & 16 & 40.04 & na & 18 & 7.6 & 410 & 7.3 \\
\hline YL_Pr193 & Crooked Creek Spring & $19(79 \%)$ & $\underline{17}$ & 43.74 & $\underline{0.75}$ & 11 & 7.6 & 407 & 6.9 \\
\hline YL_Pr194 & Crooked Creek trib & 17 (70\%) & $\overline{15}$ & 41.18 & $\overline{0.6}$ & 16 & 7.6 & 411 & 7.8 \\
\hline YL_Pr196 & Commissary Creek & 17 (70\%) & 7 & 53.93 & na & 11 & 7.6 & 493 & 6.2 \\
\hline YL_Pr202 & Rock Spring trib & $18(75 \%)$ & 12 & 50.34 & $\underline{0.75}$ & 4 & 7.5 & 485 & 9.6 \\
\hline YL_Pr212 & Sage Creek (campground) & $19(79 \%)$ & $\underline{39}$ & 46.19 & na & $\mathbf{0}$ & 7.6 & 512 & 9.8 \\
\hline YL_Pr213 & Sage Creek (below) & 19 (79\%) & $\underline{40}$ & 38.95 & na & $\mathbf{0}$ & 7.6 & 508 & 11.5 \\
\hline YL_PryS1 & Sage Creek Spring (low) & $18(75 \%)$ & $\overline{12}$ & 27.76 & 0.48 & $\mathbf{0}$ & 7.6 & 323 & 9.7 \\
\hline YL_PryS2 & Sage Creek Spring (up) & 18 (75\%) & 8 & 32.66 & 0.54 & $\mathbf{0}$ & 7.6 & 344 & 19.0 \\
\hline
\end{tabular}

Community results from the habitat and macroinvertebrate surveys combined to rank the following sites from highest biological integrity to lowest.

Overall Aquatic Ecological System Site Condition (in order of highest integrity to worst by AES):

Small Transitional Foothills Stream (AES C001y)-1) Crooked Creek (above barrier), 2) Crooked Creek (below barrier), 3) Piney Creek, 4) Sage Creek

Small Forested Headwater Stream (AES D001y)-1) Upper Crooked Creek, 2) Wyoming Creek, 3) Commissary Creek

Wyoming Basin Perennial Spring (AES code S005) - 1) Crooked Creek source spring, 2) Rock Spring (my name), 3) Commissary Creek Spring

\section{Other Invertebrates}

Most of the dry stream washes from Piney Creek and Crooked Creek drainages, including Lost Water, Cave Creek and Commissary Creek contained abundant terrestrial snail populations, the most common species appear to be the Subalpine Mountainsnail, Oreohelix subrudis (see photo). But there is also a smaller form as well (from sites \#181, 182: dry washes upstream in Piney Creek) that is perhaps Oreohelix strigosa berryi, which is a MT Species of Concern (S1S2) (P. Hendricks, MTNHP, pers. comm.).

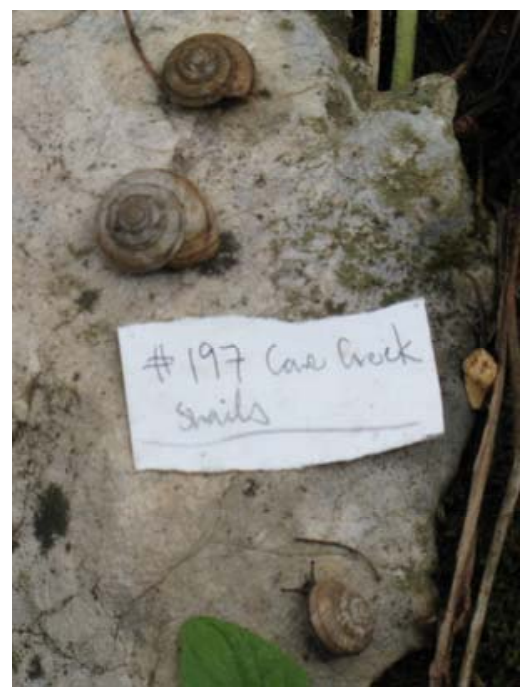




\section{Site Descriptions}

\section{Management/Threats to these ecological systems include:}

Grazing and livestock use around the riparian areas occurs and can have strong local effects resulting in sedimentation and stream widening at cattle crossings. Introductions of game or forage fish in downstream reaches or anywhere in the watershed can make their way upstream to these foothills rivers and become permanent residents.

\section{Crooked Creek (Mainstem Site \#1 below Fish Barrier)}

Location: Accessed from 4-wheel drive trail from Demijohn Flat dropped into barrier site and walked downstream $\sim 200 \mathrm{~m}$ to the first riffle/pool set designated the top of the lower reach then went $150 \mathrm{~m}$ down to start sampling in the upstream direction.

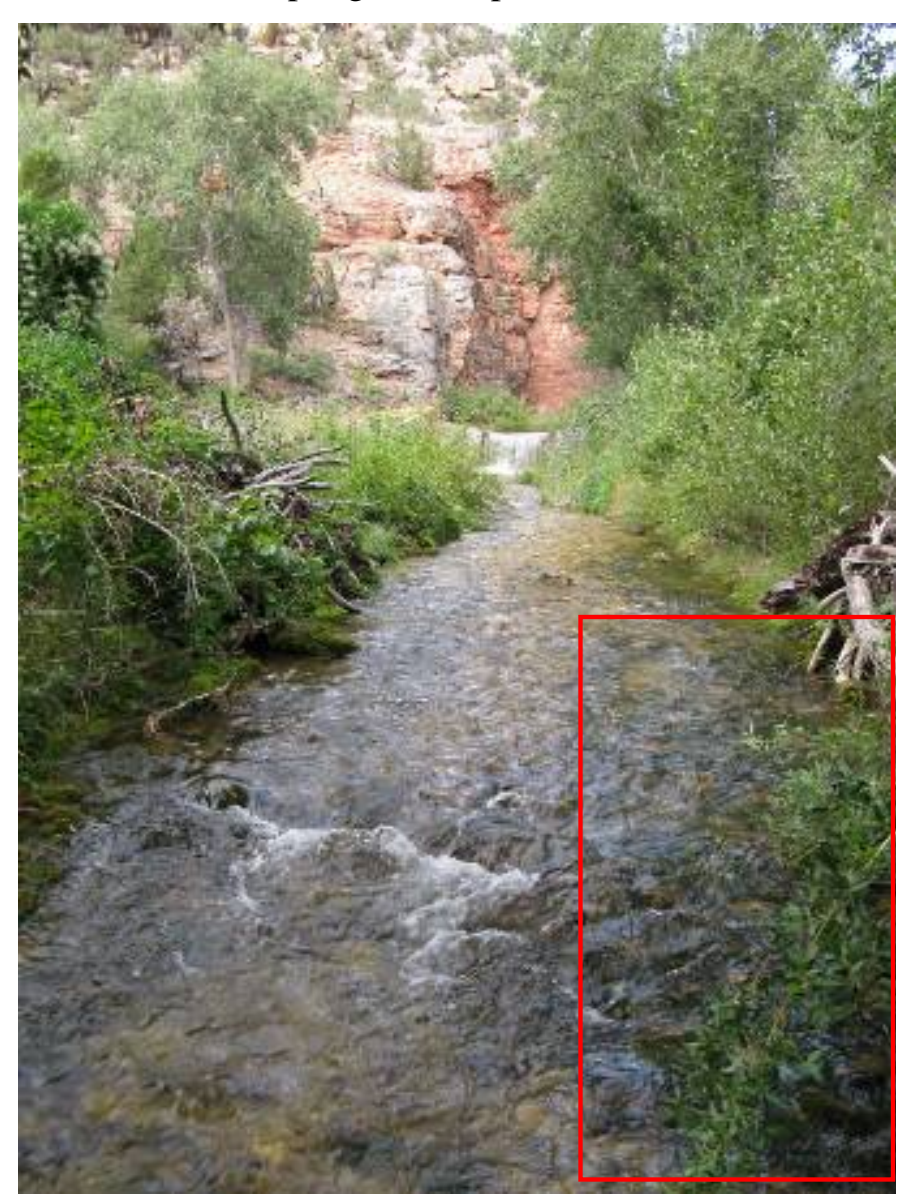

Nearest Town: Lovell, WY

Ecoregion: Wyoming Basin (Typical) Aquatic Ecological System Type: C001y. Key Environmental Factors: Upstream Riparian Grazing in the tributariessubstantial impacts, introduced fish populations. Riparian Modificationsmoderate, recovering.

Rare or Unique Species: No rare species, but a diverse foothills macroinvertebrate assemblage including Helichus striatus, a Dryopid riffle beetle found only at this site.

Rare Features: An aesthetic canyon with oasis-type qualities and a native Yellowstone cutthroat throat population.

Introduced/Exotic Aquatic Species: Introduced fish---Rainbow Trout reported in this reach below barrier (FWP MFISH, USFS pers. com.)

\section{Overall Ecological Site Condition: Good} Reach Summary: The $150 \mathrm{~m}$ reach consisted of 3 riffle/run/pool complexes with riffle/run geomorphology dominating the reach $(125 \mathrm{~m})$ averaging $0.20 \mathrm{~m}$ in depth. The mid and lower complex contain 8-10m long pools averaging $0.4 \mathrm{~m}$ in depth, and contained good fish holding habitat. This stream reach lacked a diversity of microhabitats, cobbles dominated the substrate (70\% of transects) and lacked undercut banks or large woody debris. The substrate of the pool was gravel/pebble dominated with some silt and cobbles. Vegetation coverage along the riparian stream channel was dominated by trees \& shrubs and largely intact. Livestock use index (LUI) was absent with 0 cow pies counted on a $75 \mathrm{~m}$ walk of both left and right banks.

Reach Riparian Ranking: BLM= 92\% (22 of 24) Macroinvertebrate Community Quality: MTMMI= 70.8 


\section{Crooked Creek (Mainstem Site \#2 above Fish Barrier, cover photo)}

Location: Accessed from 4-wheel drive trail from Demijohn Flat dropped into barrier site and walked upstream $\sim 200 \mathrm{~m}$ to the first riffle/pool set designated the bottom of the upper barrier reach then went $150 \mathrm{~m}$ upstream from that point to sample in the upstream direction.

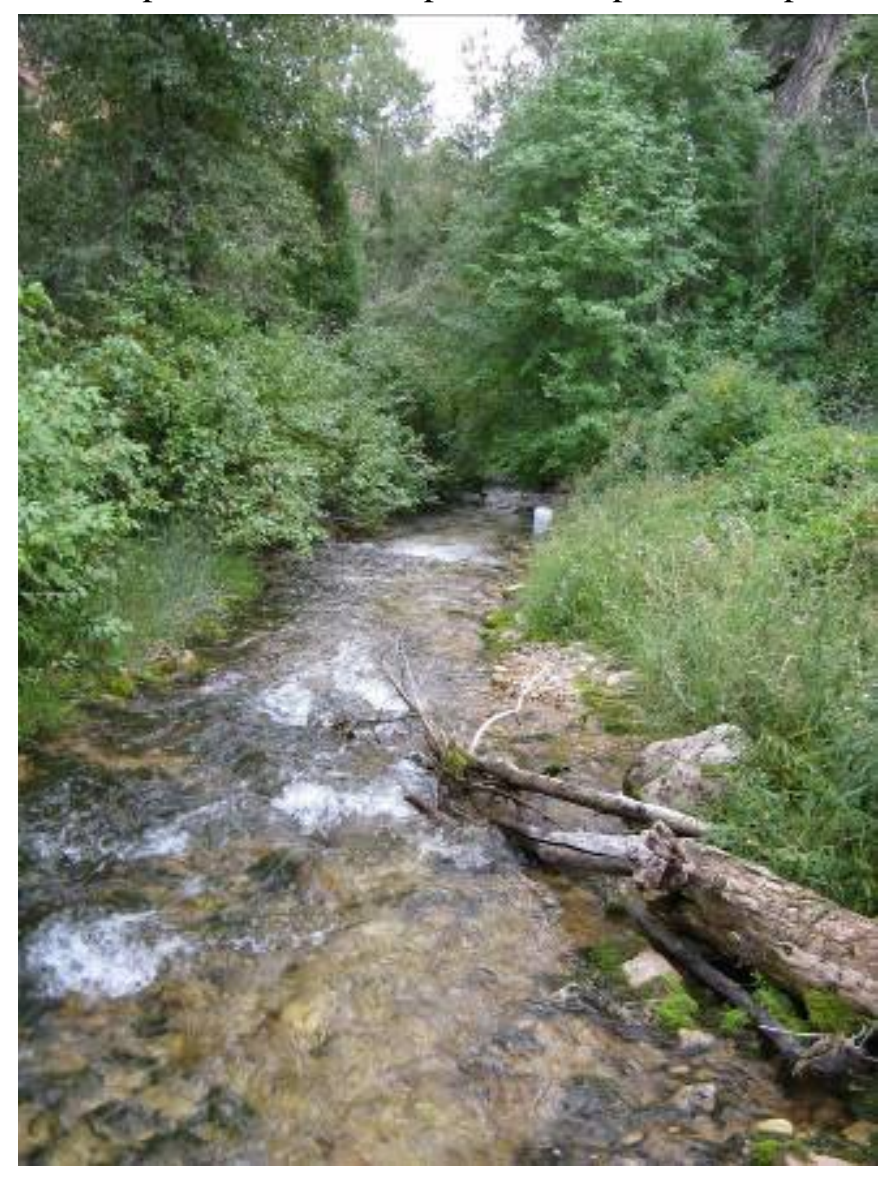

Nearest Town: Lovell, WY

Ecoregion: Wyoming Basin (Typical)

Aquatic Ecological System Type: C001y.

Key Environmental Factors: Upstream

Riparian Grazing in the tributaries: mod-

substantial impacts, introduced fish

populations: low-mitigated by the barrier.

Riparian Modifications \& grazing in the canyon are minimal. Fire-killed trees on the

steep canyon slopes $\sim 2 \mathrm{~km}$ upstream of reach.

Rare or Unique Species: No rare species, but a diverse foothills macroinvertebrate assemblage with 15 coldwater obligate taxa.

Rare Features: An aesthetic canyon with oasis-type qualities and a native Yellowstone cutthroat throat population.

Introduced/Exotic Aquatic Species: Introduced fish---Rainbow Trout reported in this reach below barrier (FWP MFISH, USFS pers. com.)

\section{Overall Ecological Site Condition: Good to Excellent}

Reach Summary: The $150 \mathrm{~m}$ reach consisted of 3 riffle/run/pool complexes with riffle/run geomorphology dominating the reach $(125 \mathrm{~m})$ averaging $0.20 \mathrm{~m}$ in depth. The mid and lower complex contains $8-10 \mathrm{~m}$ pools averaging $0.4 \mathrm{~m}$ in depth, and contained the most fish holding habitat. This stream reach lacked a large diversity of fish holding macrohabitats, cobbles dominated the substrate (70\% of transects) and lacked undercut banks and few large woody debris. The substrate of the pool was gravel/pebble dominated with some silt and cobbles. Vegetation coverage along the riparian stream channel was dominated by trees \& shrubs and largely intact. Livestock use index (LUI) was none with 0 cow pies counted on a $75 \mathrm{~m}$ walk of both left and right banks.

Reach Riparian Ranking: BLM= 100\% (24 of 24) Macroinvertebrate Community Quality: MTMMI = 75.3 


\section{Crooked Creek (Mainstem Site YL_S188 above Fish Barrier upper canyon)}

Ecoregion: Pryor/Bighorn Mountain Foothills

Aquatic Ecological System Type: D001y-Forested Headwater River

Key Environmental Factors: Riparian Grazing — slight to moderate impacts upstream, but none in the immediate reach. Fire-killed trees on the steep canyon slopes within the reach may contribute to LWD additions to the stream for increased habitat complexity.

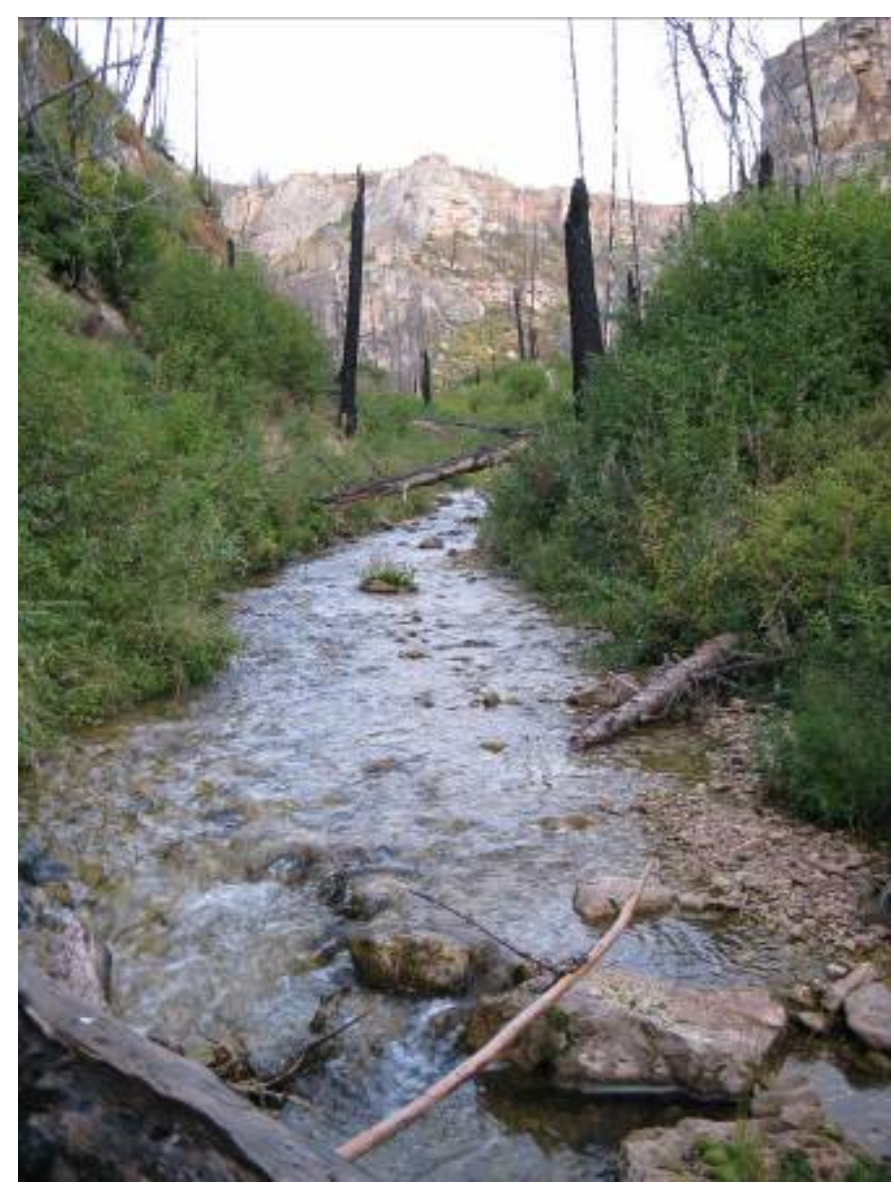

Rare or Unique Species: No rare SOC species, but abundant cold-water caddisfly, Rhyacophila hyalinata gr present in the samples

Rare Features: No rare features documented Introduced/Exotic Aquatic Species: None Overall Ecological Site Condition: Good to Excellent

Reach Summary:

This stream reach has moderate quality instream aquatic habitat with some boulder drop pools and LWD overhangs. Livestock use index (LUI) was zero, with no livestock able to access this site in the canyon.

Riparian Ranking: BLM=92\% (22 of 24) Proper Functioning Condition (PFC) Reach Riparian Geomorphology: The geomorphology of this stream reach is a Rosgen B-3 with a medium gradient (2\%), moderate sinuosity, a riffle dominated configuration with substrate dominated by cobble/boulders and pebble runs. Pools are small-largely absent averaged $>30 \mathrm{~cm}$ in depth, average wetted width of the reach was $2.8 \mathrm{~m}$.

Macroinvertebrate Community: This excellent quality community is dominated by the Traditional Trout Stream Assemblage (\#90, Stagliano 2005) and members of the Small Foothills Transitional Assemblage (\#105, Stagliano 2005), overall a diverse macroinvertebrate assemblage with 11 coldwater obligate taxa.

Macroinvertebrate Community Quality: DEQ MMI= 85.8 


\section{Wyoming Creek (YL_Pr190)}

Ecoregion: Pryor/Bighorn Mountain Foothills

Aquatic Ecological System Type: D001y-Forested Headwater Stream

Key Environmental Factors: Riparian Grazing \& Cattle Use-moderate impacts, near stream pocking. Some sediment loading from riparian trampling or upstream beaver activity.

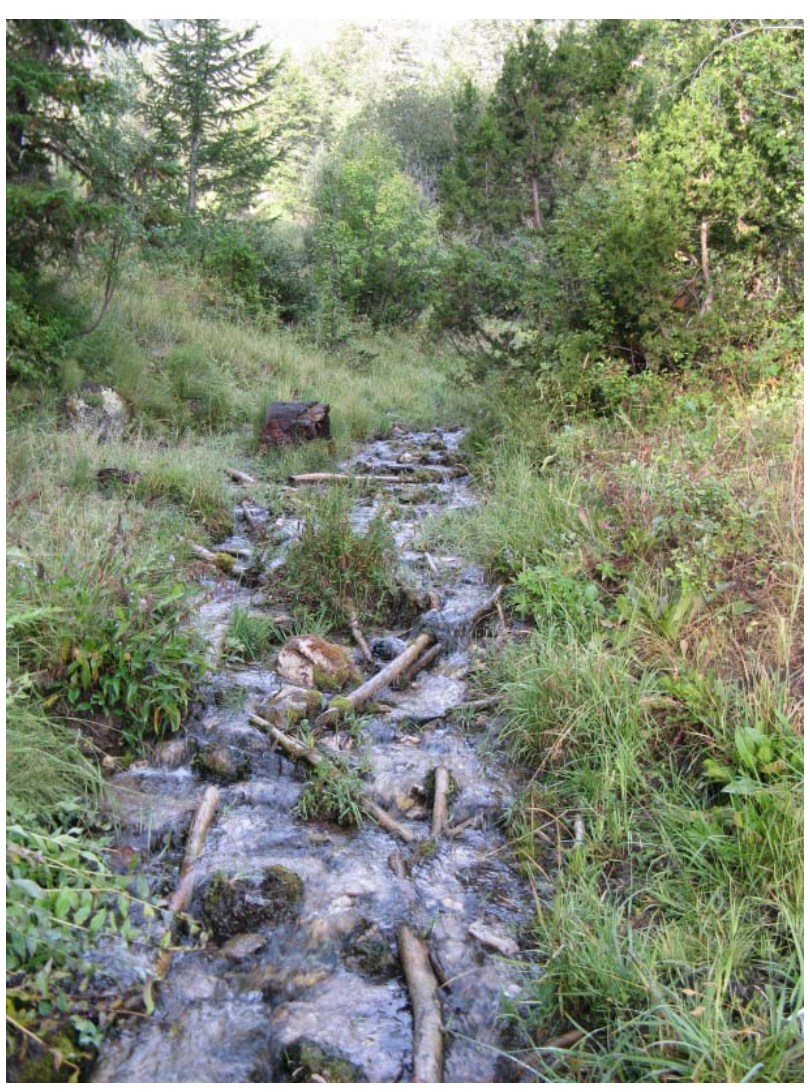

Rare or Unique Species: No SOC species, but a unique species to this assessment, the caddisfly, Rhyacophila oreta.

Rare Features: No rare features documented Introduced/Exotic Aquatic Species: None collected.

Overall Ecological Site Condition: Fair trending to Good with proper grazing management.

Reach Riparian Ranking: BLM= 18 (75\%)

Reach

Functional At Risk Riparian Condition (FAR) Geomorphology: Rosgen B4. Surrounding bank materials are finer than the channel bed materials, gravel to pebble dominated substrate, with embedded cobbles and some LWD derived from a beaver upstream? (beaver chewed sticks). Cobbles have a dense moss growing on them increasing the microhabitat diversity.

Macroinvertebrate Community: A fairly diverse community of 37 taxa, including 8 cold-water obligate taxa, despite some obvious sediment loading issues and embedded cobbles. Also contains taxa indicative of a Wyoming Basin Spring indicating obvious spring discharge influence in the drainage.

Macroinvertebrate Community Quality: MMI= 55.87 


\section{Crooked Creek Trib/Mainstem (YL_Pr191)}

Ecoregion: Bighorn-Pryor Mountains/Wyoming Basin (Typical)

Aquatic Ecological System Type: D001y-Forested Headwater Stream

Key Environmental Factors: Riparian Grazing \& Cattle Use-moderate impacts, near stream pocking. Some sediment loading from riparian trampling and instream cattle use.

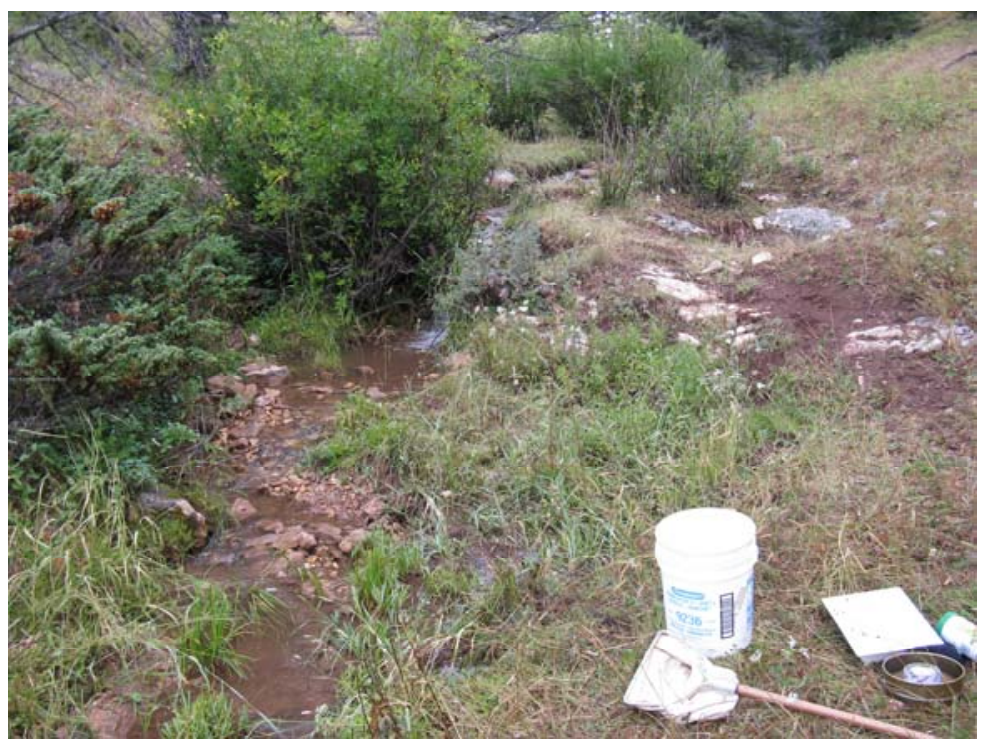

Rare or Unique Species: No SOC species, but a unique species to this assessment, Meringodixa chalonensis, a cold-water obligate dipteran taxa. Introduced/Exotic Species: None documented Overall Ecological Site Condition: Degraded/Fair trending to Good with improved cattle management.

Riparian Ranking: BLM= 17 (70\%) Functional At Risk Riparian Condition (FAR)

Fish Community: No fish species collected or expected.

Macroinvertebrate Community Quality: A fairly diverse community of 30 taxa, including 8 coldwater obligate taxa, despite some obvious impairments from sediment loading issues, riparian degradation and embedded cobbles. Also contains 6 taxa indicative of a Wyoming Basin Spring indicating obvious spring discharge influences in the drainage.

Macroinvertebrate Community Quality: DEQ MMI= 43.7 


\section{Crooked Creek Spring Source (YL_Pr193)}

\section{Ecoregion: Bighorn-Pryor Mountains/Wyoming Basin (Typical)}

Aquatic Ecological System Type: S005-Wyoming Basin Perennial Spring

Key Environmental Factors: Grazing — slight-moderate impacts, some fenced areas-but some riparian intrusions and degradation of riparian shrub, grasses and willows.

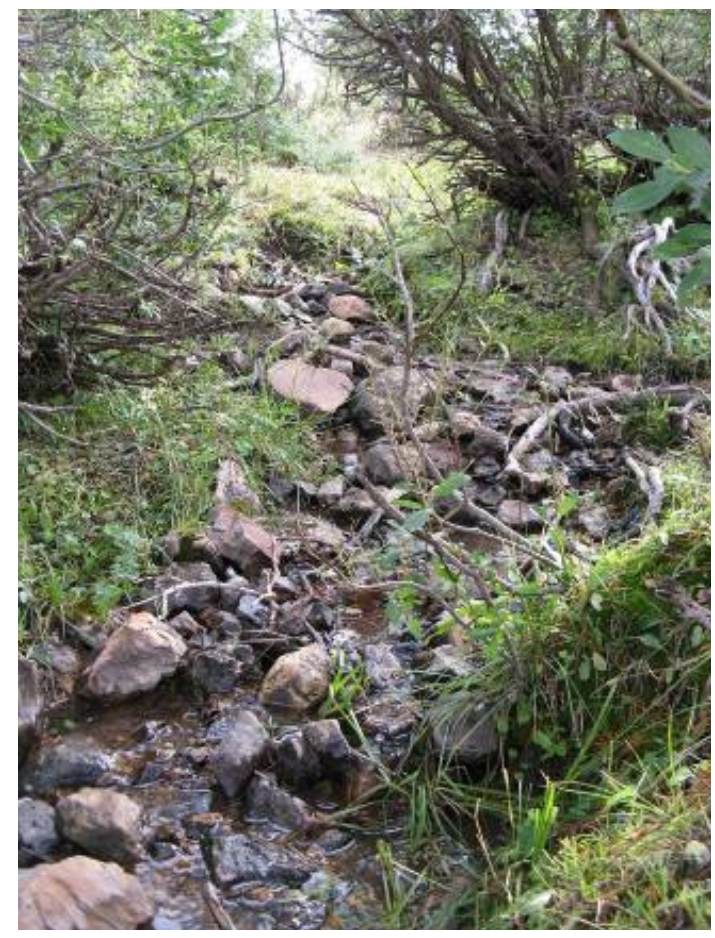

Rare or Unique Species: An oasis of a fairly healthy spring community of aquatic insects within a high forestsagebrush transition landscape.

Introduced/Exotic Species: None documented Overall Ecological Site Condition: Fair trending to Good with improved cattle management.

Reach Riparian Ranking: BLM= 79\% (19 of 24) Functional At Risk Riparian Condition (FAR) Fish Community: No fish species collected or expected.

Macroinvertebrate Community Quality O/E: The community sampled is consistent with a Wyoming Basin Perennial Spring Creek Assemblage sharing 15 of 20 reference condition invertebrates

Macroinvertebrate Community Quality: DEQ MMI= 43.7

\section{Commissary Creek (YL_Pr196)}

Ecoregion: Bighorn-Pryor Mountains/Wyoming Basin (Typical) Aquatic Ecological System Type: D001y-Forested Headwater Stream

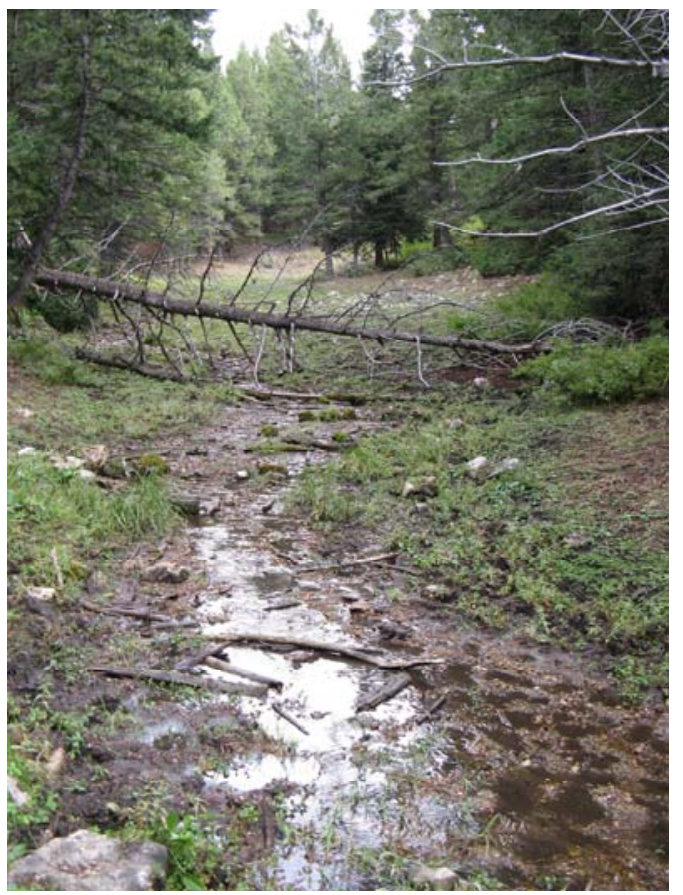

Key Environmental Factors: Grazing-slight-moderate impacts, some fenced areas-but channel intrusions and degradation have increased the width of the stream far more than it needs to be. Pocked and hummocked along the stream margins.

Rare or Unique Species: Surprisingly 2 coldwater invertebrate taxa are persisting in this degraded stream channel.

Introduced/Exotic Species: None documented Overall Ecological Site Condition: Degraded trending to Fair with improved cattle management.

Reach Riparian Ranking: BLM= 17 (70\%) FAR Macroinvertebrate Community Quality O/E: The community sampled is consistent with a moderately degraded forested headwater stream sharing only 2 coldwater taxa common to reference condition invertebrates. The MMI does not accurately reflect how degraded the community largely due to the small sample size collected.

Macroinvertebrate Community Quality: DEQ MMI= 53.9 


\section{Sage Creek Mainstem (YL_Pr212)}

Ecoregion: Bighorn-Pryor Foothills/Wyoming Basin (Typical)

Aquatic Ecological System Type: Small Transitional Foothills Stream (AES C001y)

Key Environmental Factors: Riparian Grazing \& Cattle Use-moderate impacts upstream, none in the immediate area. Heavy sediment loading from upstream riparian cattle use.

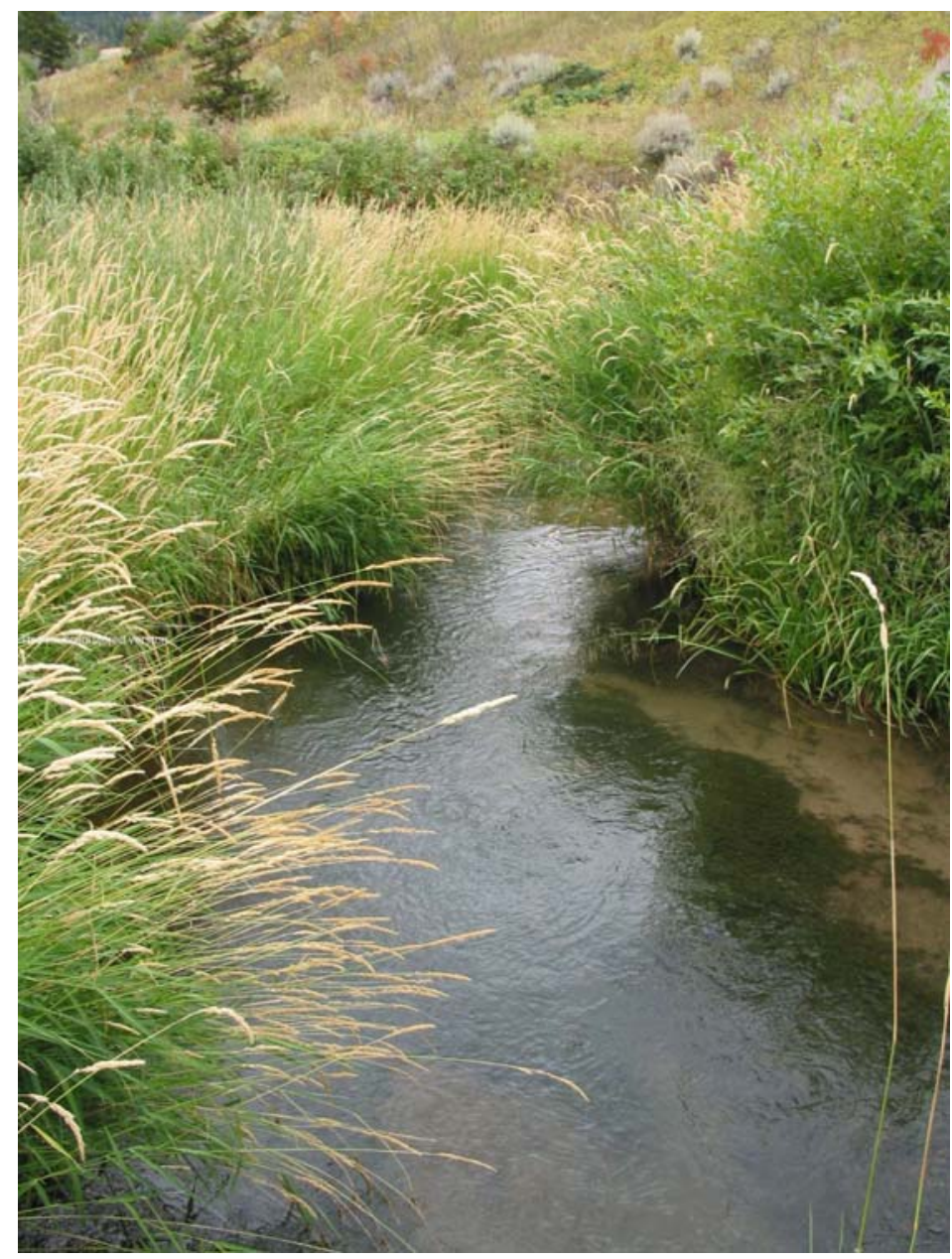

Rare or Unique Species: No SOC

species, but a two unique riffle beetles, Lara avara and Narpus concolor (coldwater obligate coleopteran taxa).

Introduced/Exotic Species: None documented

\section{Geomorphology: Rosgen F4}

Overall Ecological Site Condition:

Degraded trending to Fair with improved instream habitat conditions and upstream cattle management.

Riparian Ranking: BLM= 19 (79\%)

Functional At Risk Riparian

\section{Condition (FAR)}

\section{Macroinvertebrate Community}

Quality: A fairly diverse community of 39 taxa, including 4 cold-water obligate taxa, despite some obvious impairments from sediment loading issues, riparian degradation and heavy patches of aquatic vegetation. Community species are indicative of warmer water temps and dominance of finer benthic substrates. Macroinvertebrate Community Quality: DEQ MMI= 46.19 


\section{Piney Creek (BLM Section YL_Pr184)}

Ecoregion: Bighorn-Pryor Foothills/Wyoming Basin (Typical)

Aquatic Ecological System Type: Small Transitional Foothills Stream (AES C001y)

Key Environmental Factors: Riparian Grazing \& Cattle Use-slight impacts in the BLM section, some pocking and hummocking, none in the USFS spring outflow area. High discharge spring about 500m upstream.

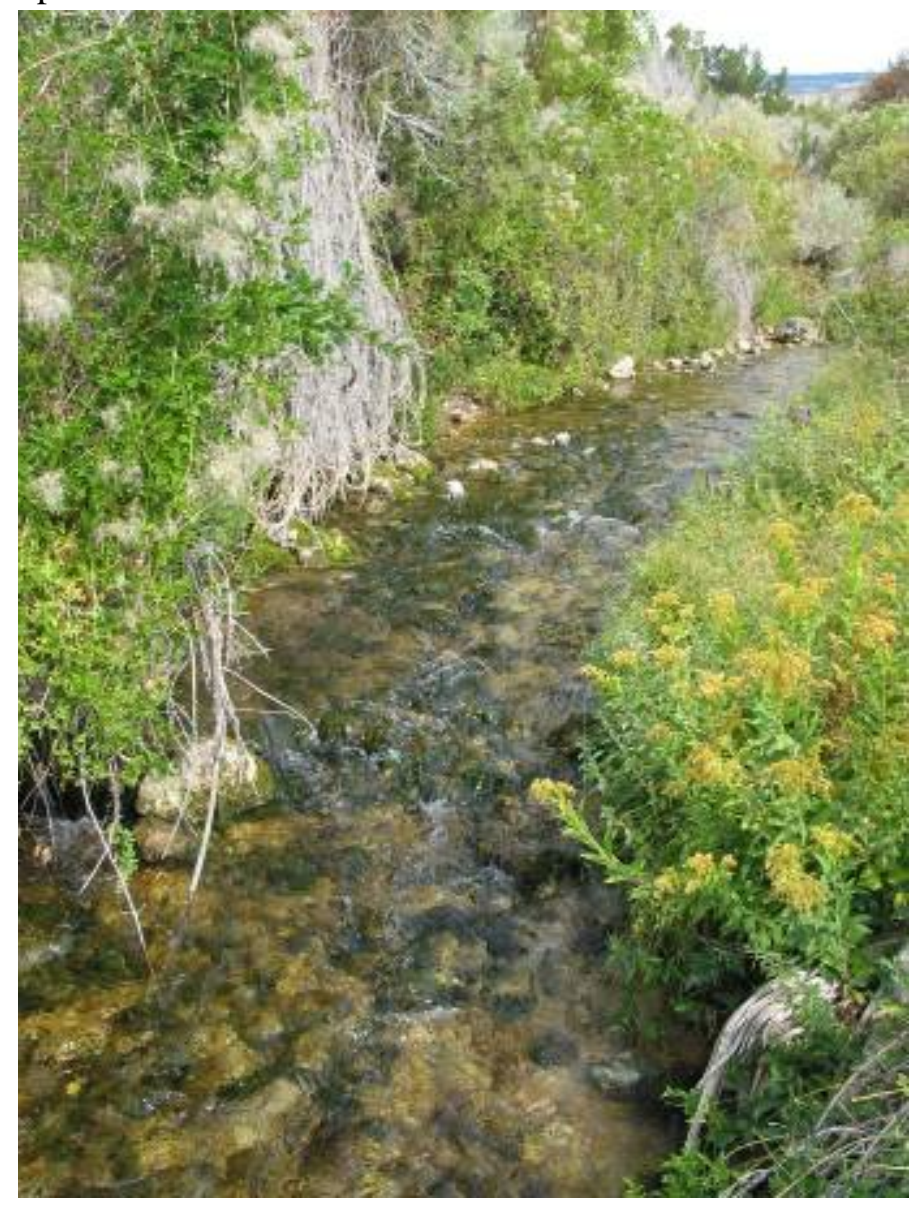

Rare or Unique Species: Reported Yellowstone cutthroat trout in reach (USFS pers. comm.). No SOC rare invertebrate species, but a good quality cold-water assemblage dominating the macroinverts.

Rare Features: No rare features documented, except a high discharge spring about 500m upstream pumping out pure snowmelt @ 5 degrees C.

Riparian Ranking: BLM= 19 (79\%) Functional At Risk Riparian Condition (FAR)

Geomorphology: Rosgen B3 Substrate looks very similar to Crooked Creek canyon sites including moss covered cobbles.

Introduced/Exotic Aquatic Species: None documented

Overall Ecological Site Condition: Good (2007 \& 2008)

Macroinvertebrate Community: A good quality \& fairly diverse community of 29 taxa, including 9 cold-water obligate taxa, despite some obvious sediment and grazing issues within the reach.

Macroinvertebrate Community Quality: MT MMI= 62.97 


\section{Literature Cited}

Barbour, M., J. Gerritsen, B.D. Snyder, and J.B. Stribling. 1999. Rapid Bioassessment Protocols for Use in Streams and Wadable Rivers: Periphyton, Benthic Macroinvertebrates and Fish,Second Edition. EPA 841-B-99-002. United States Environmental Protection Agency; Office of Water: Washington, D.C..

Feldman, D. 2006. Interpretation of New Macroinvertebrate Models by WQPB. Draft Report. Montana Department of Environmental Quality, Planning Prevention and Assistance Division, Water Quality Planning Bureau, Water Quality Standards Section.1520 E. $6^{\text {th }}$ Avenue, Helena, MT 59620. 14 pp.

Jessup, B., J. Stribling; and C. Hawkins. 2005. Biological Indicators of Stream Condition in Montana Using Macroinvertebrates. Tetra Tech, Inc. November 2005 (draft).

Jessup, B. 2006. Ecological Data Application System (EDAS) Version MT 3.3.2k A User’s Guide. Tetra Tech, Inc.

Lazorchak, J.M., Klemm, D.J., and D.V. Peck (editors). 1998. Environmental Monitoring and Assessment Program - Surface Waters: Field Operations and Methods for Measuring the Ecological Condition of Wadeable Streams. EPA/620/R-94/004F. U.S. Environmental Protection Agency, Washington, D.C.

Montana Department of Environmental Quality (DEQ). 2005. Sample Collection, Sorting, and Taxonomic Identification of Benthic Macroinvertebrates. Water Quality Planning Bureau. Standard Operation Procedure (WQPBWQM-009).

Stagliano, David, M. 2008. Aquatic Macroinvertebrate Inventory \& Assessment of Springs and Seeps within Bighorn Canyon National Recreation Area (BICA), Report to the Western National Parks Association and the Greater Yellowstone Network Inventory \& Monitoring Program, National Park Service. http://mtnhp.org/reports/BICASprings.pdf

Stagliano, David, M. 2005. Aquatic Community Classification and Ecosystem Diversity in Montana’s Missouri River Watershed. Report to the Bureau of Land Management. Montana Natural Heritage Program, Helena, Montana. 65 pp. plus appendices. http://www.mtnhp.org/reports.asp\#Ecology 
Appendix A. Macroinvertebrate Taxa / Species by site for the 2008 USFS/BLM Pryors Asseesment. O.T.U is the taxonomic unit that the MMI uses in the calculations. Rep= Replicate sample. Bolded taxa are cold-water stenotherms (obligate indicator taxa)

\begin{tabular}{|c|c|c|c|c|c|}
\hline $\begin{array}{l}\text { Crooked Creek } \\
\text { Below barrier }\end{array}$ & O.T.U & Final Taxa ID & Rep 1 & Rep 2 & \\
\hline YL_Pr186 & Dryopidae & Helichus striatus & 3 & 2 & \\
\hline YL_Pr186 & Microcylloepus & Microcylloepus pusillus & 13 & 8 & \\
\hline YL_Pr186 & Optioservus & $\begin{array}{l}\text { Optioservus } \\
\text { quadrimaculatus }\end{array}$ & 32 & 21 & \\
\hline YL_Pr186 & Chelifera_Metachela & Chelifera & 6 & 4 & \\
\hline YL_Pr186 & Chironominae & Micropsectra & 36 & 21 & \\
\hline YL_Pr186 & Chironominae & Rheotanytarsus & 31 & 20 & \\
\hline YL_Pr186 & Diamesinae & Pagastia & 55 & 33 & \\
\hline YL_Pr186 & Diamesinae & Pseudodiamesa & 9 & 6 & \\
\hline YL_Pr186 & Orthocladiinae & Eukiefferiella devonica & 23 & 12 & \\
\hline YL_Pr186 & Orthocladiinae & Eukiefferiella Gracei Gr. & 9 & 4 & \\
\hline YL_Pr186 & Orthocladiinae & Parametriocnemus & 12 & 8 & \\
\hline YL_Pr186 & Orthocladiinae & Tvetenia bavarica & 58 & 22 & \\
\hline YL_Pr186 & Simuliidae & Prosimulium & 16 & 8 & \\
\hline YL_Pr186 & Tipula & Tipula & 2 & 1 & \\
\hline YL_Pr186 & Baetis & Baetis bicaudatus & 160 & 122 & \\
\hline YL_Pr186 & Cinygmula & Cinygmula & 79 & 42 & \\
\hline YL_Pr186 & Drunella doddsi & Drunella doddsi & 14 & 5 & \\
\hline YL_Pr186 & Serratella & Serratella tibialis & 13 & 8 & \\
\hline YL_Pr186 & Amphinemura & Amphinemura banksi & 29 & 18 & \\
\hline YL_Pr186 & Doroneuria & Doroneuria theodora & 11 & 3 & \\
\hline YL_Pr186 & Hesperoperla & Hesperoperla pacifica & 26 & 11 & \\
\hline YL_Pr186 & Kogotus & Kogotus modestus & 3 & 2 & \\
\hline YL_Pr186 & Malenka & Malenka & 5 & 3 & \\
\hline YL_Pr186 & Zapada & Zapada cinctipes & 60 & 27 & \\
\hline YL_Pr186 & Brachycentrus & Brachycentrus americanus & 6 & 2 & \\
\hline YL_Pr186 & Neothremma & Neothremma alicia & 304 & 176 & \\
\hline YL_Pr186 & Parapsyche & Parapsyche elsis & 10 & 7 & \\
\hline YL_Pr186 & Psychoglypha & Psychoglypha & 3 & 1 & \\
\hline YL_Pr186 & Rhyacophila brunnea Gr. & Rhyacophila Brunnea Gr. & 20 & 8 & \\
\hline \multirow[t]{2}{*}{ YL_Pr186 } & Rhyacophila sibirica gr. & Rhyacophila narvae & 1 & 0 & \\
\hline & & Total Taxa & 30 & 29 & 29.5 \\
\hline \multicolumn{6}{|l|}{$\begin{array}{l}\text { Crooked } \\
\text { Creek Above } \\
\text { barrier }\end{array}$} \\
\hline YL_Pr187 & Ameletus & Ameletus similior & 30 & 22 & \\
\hline YL_Pr187 & Turbellaria & Polycelis coronata & 24 & 13 & \\
\hline YL_Pr187 & Heterlimnius & Heterlimnius corpulentus & 11 & 11 & \\
\hline YL_Pr187 & Microcylloepus & Microcylloepus pusillus & 5 & 0 & \\
\hline YL_Pr187 & Optioservus & $\begin{array}{l}\text { Optioservus } \\
\text { quadrimaculatus }\end{array}$ & 5 & 0 & \\
\hline YL_Pr187 & Chelifera_Metachela & Chelifera & 6 & 4 & \\
\hline YL_Pr187 & Chironominae & Micropsectra & 95 & 45 & \\
\hline YL_Pr187 & Chironominae & Rheotanytarsus & 11 & 0 & \\
\hline YL_Pr187 & Diamesinae & Pagastia & 28 & 7 & \\
\hline YL_Pr187 & Diamesinae & Pseudodiamesa & 1 & 0 & \\
\hline
\end{tabular}




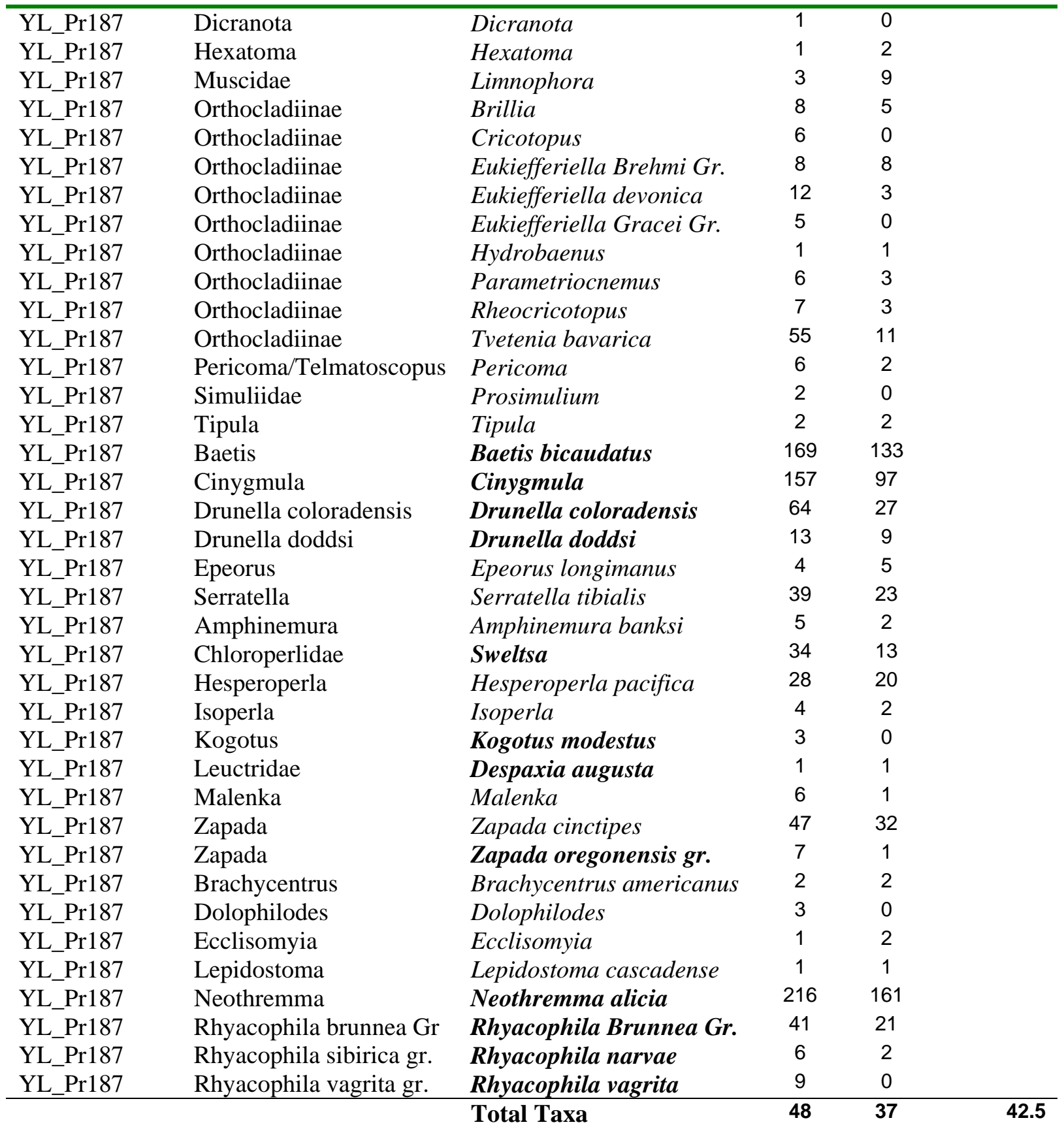




\begin{tabular}{|c|c|c|c|c|c|}
\hline $\begin{array}{l}\text { Crooked } \\
\text { Creek upper } \\
\text { canyon }\end{array}$ & Final Taxa ID & $\begin{array}{l}\text { \# of } \\
\text { Indiv. }\end{array}$ & $\begin{array}{l}\text { Piney } \\
\text { Creek } \\
\text { (BLM) }\end{array}$ & Final Taxa ID & $\begin{array}{l}\text { \# of } \\
\text { Indiv. }\end{array}$ \\
\hline YL_Pr188 & Amphinemura banksi & 3 & YL_Pr184 & Amphinemura banksi & 35 \\
\hline YL_Pr188 & Baetis bicaudatus & 24 & YL_Pr184 & Atractides & 2 \\
\hline YL_Pr188 & Brillia & 3 & YL_Pr184 & Baetis tricaudatus & 110 \\
\hline YL_Pr188 & Chelifera & 2 & YL_Pr184 & Brillia & 25 \\
\hline YL_Pr188 & Cinygmula & 60 & YL_Pr184 & Cinygmula & 75 \\
\hline YL_Pr188 & Dicranota & 1 & YL_Pr184 & Cricotopus & 5 \\
\hline YL_Pr188 & Dolophilodes & 3 & YL_Pr184 & Diamesa & 2 \\
\hline YL_Pr188 & Drunella coloradensis & 64 & YL_Pr184 & Dicranota & 18 \\
\hline YL_Pr188 & Epeorus longimanus & 4 & YL_Pr184 & Drunella coloradensis & 35 \\
\hline YL_Pr188 & Isoperla & 2 & YL_Pr184 & Eukiefferiella devonica & 12 \\
\hline YL_Pr188 & Kogotus modestus & 3 & YL_Pr184 & Eukiefferiella gracei & 2 \\
\hline YL_Pr188 & Lepidostoma cascadense & 1 & YL_Pr184 & Helophorus & 2 \\
\hline YL_Pr188 & Limnophora & 3 & YL_Pr184 & Heterlimnius corpulentus & 30 \\
\hline YL_Pr188 & Malenka & 6 & YL_Pr184 & $\begin{array}{l}\text { Heterotrissocladius } \\
\text { marcidus }\end{array}$ & 5 \\
\hline YL_Pr188 & Micropsectra & 5 & YL_Pr184 & Kogotus modestus & 5 \\
\hline YL_Pr188 & Neothremma alicia & 2 & YL_Pr184 & Limnophora & 1 \\
\hline YL_Pr188 & $\begin{array}{l}\text { Optioservus } \\
\text { quadrimaculatus }\end{array}$ & 5 & YL_Pr184 & Neothremma alicia & 220 \\
\hline YL_Pr188 & Pagastia & 4 & YL_Pr184 & Paraleptophlebia & 5 \\
\hline YL_Pr188 & Parametriocnemus & 5 & YL_Pr184 & Polycelis coronata & 98 \\
\hline YL_Pr188 & Pericoma & 4 & YL_Pr184 & Protzia & 2 \\
\hline YL_Pr188 & Polycelis coronata & 11 & YL_Pr184 & Pseudodiamesa & 5 \\
\hline YL_Pr188 & Rheocricotopus & 4 & YL_Pr184 & Rheocricotopus & 65 \\
\hline YL_Pr188 & Rhyacophila brunnea gr. & 3 & YL_Pr184 & Rheotanytarsus & 12 \\
\hline YL_Pr188 & Rhyacophila hyalinata gr. & 31 & YL_Pr184 & Rhyacophila brunnea gr. & 11 \\
\hline YL_Pr188 & Rhyacophila vagrita & 9 & YL_Pr184 & Sweltsa & 15 \\
\hline YL_Pr188 & Serratella tibialis & 11 & YL_Pr184 & Testudacarus & 1 \\
\hline YL_Pr188 & Sweltsa & 31 & YL_Pr184 & Tipula & 4 \\
\hline YL_Pr188 & Zapada cinctipes & 3 & YL_Pr184 & Zapada cinctipes & 3 \\
\hline \multirow[t]{2}{*}{ YL_Pr188 } & Zapada Oregonensis gr. & 6 & & & \\
\hline & Total Taxa & 29 & & Total Taxa & 28 \\
\hline
\end{tabular}




\begin{tabular}{|c|c|c|}
\hline \multicolumn{3}{|c|}{ Appendix A. Continued. } \\
\hline $\begin{array}{l}\text { Wyoming } \\
\text { Creek }\end{array}$ & Final Taxa ID & $\begin{array}{l}\text { \# of } \\
\text { Indiv. }\end{array}$ \\
\hline UYL_WY5 & Amphinemura banksi & 54 \\
\hline UYL_WY5 & Baetis bicaudatus & 4 \\
\hline UYL_WY5 & Baetis tricaudatus & 17 \\
\hline UYL_WY5 & Brillia & 100 \\
\hline UYL_WY5 & Cardiocladius & 7 \\
\hline UYL_WY5 & Clinocera & 1 \\
\hline UYL_WY5 & Cricotopus & 18 \\
\hline UYL_WY5 & Dicranota & 3 \\
\hline UYL_WY5 & Dixa & 3 \\
\hline UYL_WY5 & Drunella coloradensis & 1 \\
\hline UYL_WY5 & Drunella doddsi & 2 \\
\hline UYL_WY5 & Ephemerella excrucians & 1 \\
\hline UYL_WY5 & Eukiefferiella brehmi gr. & 22 \\
\hline UYL_WY5 & Eukiefferiella devonica & 2 \\
\hline UYL_WY5 & Eukiefferiella gracei gr. & 10 \\
\hline UYL_WY5 & Euparyphus & 2 \\
\hline UYL_WY5 & Isoperla & 1 \\
\hline UYL_WY5 & Lepidostoma cascadense & 2 \\
\hline UYL_WY5 & Limnephilus & 1 \\
\hline UYL_WY5 & Limnophora & 2 \\
\hline UYL_WY5 & Micropsectra & 25 \\
\hline UYL_WY5 & Neothremma alicia & 2 \\
\hline UYL_WY5 & Orthocladius & 6 \\
\hline UYL_WY5 & Ostracoda & 10 \\
\hline UYL_WY5 & Pagastia & 20 \\
\hline UYL_WY5 & Parakiefferiella & 10 \\
\hline UYL_WY5 & Parametriocnemus & 5 \\
\hline UYL_WY5 & Polycelis coronata & 51 \\
\hline UYL_WY5 & Pseudodiamesa & 15 \\
\hline UYL_WY5 & Rheocricotopus & 14 \\
\hline UYL_WY5 & Rhyacophila brunnea gr. & 12 \\
\hline UYL_WY5 & Rhyacophila oreta & 1 \\
\hline UYL_WY5 & Sweltsa & 26 \\
\hline UYL_WY5 & Tipula & 5 \\
\hline UYL_WY5 & Tubificidae & 2 \\
\hline UYL_WY5 & Tvetenia bavarica & 6 \\
\hline UYL_WY5 & Zapada Oregonensis gr. & 27 \\
\hline & Total Taxa & 37 \\
\hline
\end{tabular}




\begin{tabular}{|c|c|c|c|c|c|}
\hline \multicolumn{6}{|c|}{ Appendix A. Continued. } \\
\hline $\begin{array}{l}\text { Crooked } \\
\text { Creek } \\
\text { trib/upper } \\
\text { canyon }\end{array}$ & Final Taxa ID & $\begin{array}{c}\text { \# of } \\
\text { Indiv. }\end{array}$ & $\begin{array}{r}\text { Crooked } \\
\text { Creek } \\
\text { source }\end{array}$ & Final Taxa ID & $\begin{array}{c}\text { \# of } \\
\text { Indiv. }\end{array}$ \\
\hline YL_Pr191 & Amphinemura banksi & 66 & YL_Pr192 & Ablabesmyia & 1 \\
\hline YL_Pr191 & Baetis bicaudatus & 5 & YL_Pr192 & Amphinemura banksi & 11 \\
\hline YL_Pr191 & Brachycentrus americanus & 40 & YL_Pr192 & Atractides & 2 \\
\hline YL_Pr191 & Diamesa & 12 & YL_Pr192 & Caloparyphus & 1 \\
\hline YL_Pr191 & Dicranota & 25 & YL_Pr192 & Cinygmula & 1 \\
\hline YL_Pr191 & Diphetor hageni & 4 & YL_Pr192 & Euparyphus & 2 \\
\hline YL_Pr191 & Eukiefferiella Gracei Gr. & 3 & YL_Pr192 & Fossaria humilis & 5 \\
\hline YL_Pr191 & Euparyphus & 4 & YL_Pr192 & Hesperophylax designatus & 3 \\
\hline YL_Pr191 & Heterlimnius corpulentus & 86 & YL_Pr192 & Hydrobius & 1 \\
\hline YL_Pr191 & Hydrobaenus & 48 & YL_Pr192 & Limnephilus & 15 \\
\hline YL_Pr191 & Kogotus modestus & 8 & YL_Pr192 & Micropsectra & 2 \\
\hline YL_Pr191 & Meringodixa chalonensis & 5 & YL_Pr192 & Ochthebius & 1 \\
\hline YL_Pr191 & Micrasema bactro & 2 & YL_Pr192 & Parametriocnemus & 3 \\
\hline YL_Pr191 & Monodiamesa & 6 & YL_Pr192 & Simulium & 25 \\
\hline YL_Pr191 & Neothremma alicia & 5 & YL_Pr192 & Sphaerium & 4 \\
\hline YL_Pr191 & Ochthebius & 1 & & Total Taxa & 15 \\
\hline YL_Pr191 & Optioservus quadrimaculatus & 7 & & & \\
\hline YL_Pr191 & Ostracoda & 22 & & & \\
\hline YL_Pr191 & Pagastia & 17 & & & \\
\hline YL_Pr191 & Pericoma & 2 & & & \\
\hline YL_Pr191 & Polycelis coronata & 45 & & & \\
\hline YL_Pr191 & Pseudodiamesa & 11 & & & \\
\hline YL_Pr191 & Psychoglypha & 4 & & & \\
\hline YL_Pr191 & Radotanypus & 2 & & & \\
\hline YL_Pr191 & Rhyacophila Brunnea Gr. & 25 & & & \\
\hline YL_Pr191 & Serratella tibialis & 7 & & & \\
\hline YL_Pr191 & Simulium & 5 & & & \\
\hline YL_Pr191 & Sphaerium fabale & 5 & & & \\
\hline YL_Pr191 & Tanytarsus & 2 & & & \\
\hline \multirow[t]{2}{*}{ YL_Pr191 } & Zapada cinctipes & 2 & & & \\
\hline & Total Taxa & 30 & & & \\
\hline
\end{tabular}


Appendix A. Continued.

\begin{tabular}{llcllc}
\hline $\begin{array}{l}\text { Sage } \\
\text { Creek }\end{array}$ & Final Taxa ID & $\begin{array}{c}\text { \# of } \\
\text { Indiv. }\end{array}$ & $\begin{array}{l}\text { Commissary } \\
\text { Creek }\end{array}$ & Final Taxa ID & \# of \\
Springs & & 4 & YL_Pr196 & Cinygmula \\
YL_PryS1 & Argia & 2 & YL_Pr196 & Hydrobaenus & 88 \\
YL_PryS1 & Caloparyphus & 5 & YL_Pr196 & Polycelis coronata & 25 \\
YL_PryS1 & Sphaerium & 4 & YL_Pr196 & Tvetenia bavarica & 23 \\
YL_PryS1 & Baetis tricaudatus & 2 & YL_Pr196 & Pseudodiamesa & 12 \\
YL_PryS1 & Tubificidae & 7 & YL_Pr196 & Hesperophylax designatus & 6 \\
YL_PryS1 & Fossaria humilis & 9 & YL_Pr196 & Amphinemura banksi & 12 \\
YL_PryS1 & Hesperophylax designatus & 1 & & Total Taxa & 22 \\
YL_PryS1 & Valvata lewisi & 1 & Rock Creek & & $\mathbf{7}$ \\
YL_PryS1 & Radotanypus & & Spring & & \\
& & 1 & YL_Pr202 & Limnophora & 4 \\
YL_PryS1 & Pseudosuccinea columella & 2 & YL_Pr202 & Pseudodiamesa & 11 \\
YL_PryS1 & Cymbiodyta & 2 & YL_Pr202 & Zapada Oregonensis gr. & 1 \\
YL_PryS1 & Hydroporus & $\mathbf{1 2}$ & YL_Pr202 & Baetis tricaudatus & 45 \\
& Total Taxa & & YL_Pr202 & Tanytarsus & 5 \\
& & 12 & YL_Pr202 & Amphinemura banksi & 77 \\
YL_PryS2 & Caloparyphus & 5 & YL_Pr202 & Diamesa & 5 \\
YL_PryS2 & Sphaerium & 13 & YL_Pr202 & Hydrobaenus & 25 \\
YL_PryS2 & Baetis tricaudatus & 9 & YL_Pr202 & Diphetor hageni & 3 \\
YL_PryS2 & Hesperophylax designatus & 4 & YL_Pr202 & Dicranota & 2 \\
YL_PryS2 & Valvata lewisi & 4 & YL_Pr202 & Parametriocnemus & 4 \\
YL_PryS2 & Radotanypus & Cymbiodyta & YL_Pr202 & Polycelis coronata & 32 \\
YL_PryS2 & Cymphiagrion abbreviatum & 3 & & Total Taxa & $\mathbf{1 2}$ \\
YL_PryS2 & Amphian & \\
& Total Taxa & $\mathbf{8}$ & & & \\
\hline
\end{tabular}


Appendix A. Continued.

\begin{tabular}{|c|c|c|c|c|c|}
\hline $\begin{array}{l}\text { Sage Creek } \\
\text { (campground) }\end{array}$ & Final Taxa ID & $\begin{array}{l}\text { \# of } \\
\text { Indiv. }\end{array}$ & $\begin{array}{r}\text { Sage } \\
\text { Creek } \\
\text { (down) }\end{array}$ & Final Taxa ID & $\begin{array}{l}\text { \# of } \\
\text { Indiv. }\end{array}$ \\
\hline YL_Pr212 & Ameletus oregonensis & 6 & YL_Pr213 & Ameletus oregonensis & 1 \\
\hline YL_Pr212 & Amphinemura banksi & 30 & YL_Pr213 & Amphinemura banksi & 22 \\
\hline YL_Pr212 & Baetis tricaudatus & 14 & YL_Pr213 & Baetis tricaudatus & 53 \\
\hline YL_Pr212 & Brachycentrus americanus & 1 & YL_Pr213 & Brachycentrus americanus & 23 \\
\hline YL_Pr212 & Cleptelmis addenda & 2 & YL_Pr213 & Cleptelmis addenda & 6 \\
\hline YL_Pr212 & Diphetor hageni & 4 & YL_Pr213 & Diphetor hageni & 5 \\
\hline YL_Pr212 & Ecclisomyia & 1 & YL_Pr213 & Ecclisomyia & 1 \\
\hline YL_Pr212 & Ephemerella excrucians & 15 & YL_Pr213 & Ephemerella excrucians & 23 \\
\hline YL_Pr212 & Hydroptila & 1 & YL_Pr213 & Hydroptila & 7 \\
\hline YL_Pr212 & Lara avara & 1 & YL_Pr213 & Lara avara & 5 \\
\hline YL_Pr212 & Larsia & 3 & YL_Pr213 & Larsia & 1 \\
\hline YL_Pr212 & Lepidostoma unicolor & 3 & YL_Pr213 & Lepidostoma unicolor & 1 \\
\hline YL_Pr212 & Limnophila & 1 & YL_Pr213 & Limnophila & 2 \\
\hline YL_Pr212 & Lumbricina & 5 & YL_Pr213 & Lumbricina & 11 \\
\hline YL_Pr212 & Micrasema bactro & 3 & YL_Pr213 & Micrasema bactro & 6 \\
\hline YL_Pr212 & Musculium & 10 & YL_Pr213 & Musculium & 10 \\
\hline YL_Pr212 & Narpus concolor & 2 & YL_Pr213 & Narpus concolor & 4 \\
\hline YL_Pr212 & Odontomesa & 1 & YL_Pr213 & Odontomesa & 1 \\
\hline YL_Pr212 & Optioservus & 1 & YL_Pr213 & Optioservus & 7 \\
\hline YL_Pr212 & Oreodytes & 1 & YL_Pr213 & Oreodytes & 1 \\
\hline YL_Pr212 & Pagastia & 7 & YL_Pr213 & Pagastia & 2 \\
\hline YL_Pr212 & Paraleptophlebia & 90 & YL_Pr213 & Paraleptophlebia & 36 \\
\hline YL_Pr212 & Parametriocnemus & 2 & YL_Pr213 & Parametriocnemus & 12 \\
\hline YL_Pr212 & Pentaneura & 1 & YL_Pr213 & Pentaneura & 7 \\
\hline YL_Pr212 & Physella & 3 & YL_Pr213 & Physella & 31 \\
\hline YL_Pr212 & Pisidium & 40 & YL_Pr213 & Pisidium & 40 \\
\hline YL_Pr212 & Polycentropus & 4 & YL_Pr213 & Pseudodiamesa & 2 \\
\hline YL_Pr212 & Prodiamesa & 2 & YL_Pr213 & Ptychoptera & 44 \\
\hline YL_Pr212 & Pseudodiamesa & 1 & YL_Pr213 & Radotanypus & 1 \\
\hline YL_Pr212 & Ptychoptera & 34 & YL_Pr213 & Rheocricotopus & 6 \\
\hline YL_Pr212 & Radotanypus & 7 & YL_Pr213 & Rhyacophila brunnea gr. & 2 \\
\hline YL_Pr212 & Rheocricotopus & 6 & YL_Pr213 & Serratella tibialis & 5 \\
\hline YL_Pr212 & Rhyacophila brunnea gr. & 5 & YL_Pr213 & Sialis velata & 2 \\
\hline YL_Pr212 & Serratella tibialis & 4 & YL_Pr213 & Simulium & 33 \\
\hline YL_Pr212 & Sialis velata & 2 & YL_Pr213 & Thienemannimyia gr. & 12 \\
\hline YL_Pr212 & Simulium & 13 & YL_Pr213 & Tipula & 4 \\
\hline YL_Pr212 & Thienemannimyia gr. & 2 & YL_Pr213 & Zapada cinctipes & 17 \\
\hline YL_Pr212 & Tipula & 3 & YL_Pr213 & Tubificidae & 11 \\
\hline \multirow[t]{2}{*}{ YL_Pr212 } & Zapada oregonensis gr. & 2 & & & \\
\hline & Total Taxa & 39 & & Total Taxa & 38 \\
\hline
\end{tabular}

